\title{
15. CENOZOIC DEEP WATER BENTHIC FORAMINIFERS, BAY OF BISCAY
}

\author{
Detmar Schnitker, Department of Oceanography, University of Maine at Orono, Walpole, Maine
}

\begin{abstract}
Benthic foraminifers from Holes 400A, 401, and 402 of DSDP-IPOD Leg 48 have been quantitatively analyzed. These sites were drilled near the base of the continental margin of the northwestern Bay of Biscay, Hole $400 \mathrm{~A}$ at 4399 meters, Site 401 at 2495 meters, and Site 402 at 2339 meters depth. Hole $400 \mathrm{~A}$ cores contained a continuous sequence of middle Paleocene to Holocene sediments, Site 401 cores contained sediments of early Paleocene to late Eocene age, and Site 402 cores were of late Eocene and Plio-Pleistocene age. More than 450 species were separated from this material. Cluster analysis of the Paleogene data of Holes $400 \mathrm{~A}$ and 401 shows that the faunas at both sites were strongly dissimilar, suggesting that an oceanic stratification existed as early as the late Paleocene. Down core (time series) factor analysis of Hole 400A foraminiferal counts revealed the succession of five distinct faunas: a Paleocene fauna, a mid-early Eocene to earliest Oligocene fauna, an early Oligocene to late-middle Miocene fauna, and two faunas for the late Miocene to Holocene sequence. Four distinct faunas were found at Site 401: a Paleocene fauna, an Eocene fauna, and two Quaternary faunas. The high rates of faunal turnover at the end of the Paleocene, the earliest Oligocene, and during the late-middle Miocene are thought to have been caused by changes in the deep thermohaline circulation regime. The alternation of two distinct faunas from the latest Miocene to the Recent corresponds to an alternation of glacial and interglacial modes of thermohaline circulation which became accentuated during the late Pliocene.
\end{abstract}

\section{INTRODUCTION}

When compared with the volume of knowledge that is available about shallow water benthic foraminifers, the existing knowledge of Cenozoic deep water foraminifers is scanty indeed. The primary reason for this comparable dearth of publications is, without doubt, the fact that deep water deposits are not readily accessible. Sites where deep water deposits have been raised above sea level are concentrated around the Caribbean and along the former Tethys (Alps, Appenines, Caucasus). It is from these areas that the material for most of the pioneer descriptive and taxonomic work originated. The investigation of the deep-sea floor with grab samples and piston cores recovered mostly sediments of Quaternary age. It is only with the onset of the Deep Sea Drilling Project that truly oceanic deep water sediments of Mesozoic and Cenozoic age became available for study. However, in contrast to the planktonic foraminifers, the benthic foraminifers contained in the DSDP cores were only rarely subjected to detailed study. The primary goal of most investigations has been the establishment and refinement of a global biostratigraphic scheme and, to a lesser extent, the recognition of a worldwide zoogeography for those surface dwelling organisms.

The world ocean, however, is a three-dimensional body of water where both the surface and the deep water are of great significance in the formation of worldwide climate, or where both are reacting to it. The present-day cold deep water covers and controls what can be considered the world's largest single biotope. Benthic foraminifers, together with the very rare ostracodes, are the only remains of deep-sea benthic life which transmit a record of the past ocean's bottom conditions. In documenting the evolution of the deep water foraminiferal assemblages an appreciation of the evolution of world climate, particularly at high latitudes where the deep, cold waters originate and the configuration of ocean basins, the rise or subsidence of deep thresholds, etc., is gained.

Owing to the great uniformity of the deep-sea biotope, the benthic species inhabiting it are essentially worldwide in distribution; many species also have limited stratigraphic ranges. Thus, benthic deep water foraminifers are well suited for wide ranging biostratigraphic correlation. Benthic foraminiferal biostratigraphy has an additional advantage in very deep water deposits where planktonic foraminifers are dissolved: benthic species, being more resistant to dissolution by aggressive bottom waters, persist to often several hundreds of meters below the planktonic foraminiferal carbonate compensation depth (Parker and Berger, 1971).

Documenting the Cenozoic paleoceanographic evolution of the northeastern Atlantic Ocean as seen through the changes in the benthic foraminiferal populations and the calibration of benthic foraminiferal biostratigraphy with respect to the planktonic foraminiferal and nannofossil biostratigraphic schemes were the primary goals of this study.

\section{GEOGRAPHIC AND OCEANOGRAPHIC SETTING}

Holes 400A, 401, and 402 were drilled at the continental margin of the northwestern Bay of Biscay (Figure 1): Hole 


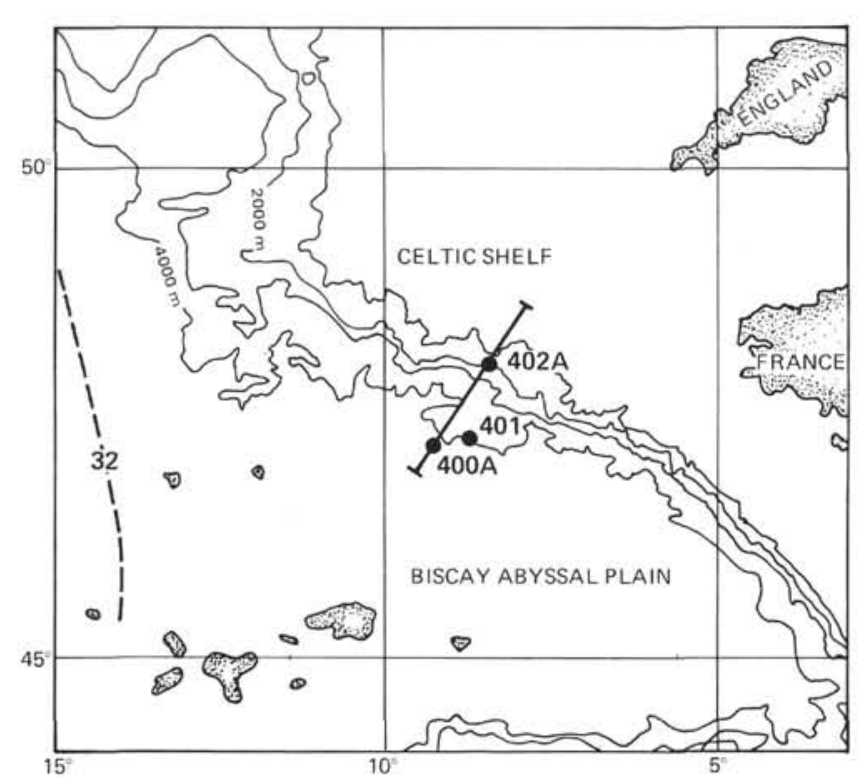

Figure 1. Location of IPOD-DSDP Holes 400A, 401, and 402 in the Bay of Biscay.

$400 \mathrm{~A}$ at 4399 meters, Site 401 at 2495 meters, and Site 402 at 2339 meters depth. This particular setting had the advantage that Hole 400A and Site 401 are essentially protected from downslope mass movements (Figure 2). Contamination with shallow water species occurred only at Site 402 .

At the present time North Atlantic Deep Water $\left(2^{\circ}-2.2^{\circ} \mathrm{C}\right.$; $34.91 \% 0-34.92 \%$ S) occupies Hole 400A; North Atlantic Deep Water with a strong admixture of Mediterranean Water $\left(3^{\circ}-3.2^{\circ} \mathrm{C} ; 34.97 \% 00-34.98 \%\right.$ S) occupies Sites 401 and 402 (Worthington and Wright, 1970).

\section{MATERIALS AND METHODS}

Cenozoic sediments were recovered from Hole 400A through the "mudline" core and continuous coring from -74.5 meters to -635 meters at which depth Maestrichtian chalk was encountered. With the exception of late middle Eocene and late Eocene sediments, a stratigraphically complete sequence of middle Paleocene to Holocene sediments was recovered. At Site 401 the "mudline" core contained late Quaternary foraminifer ooze; continuous coring from -84.5 meters to -236.5 meters recovered sediments of early Paleocene to late Eocene age. At Site 402 discontinuous

N

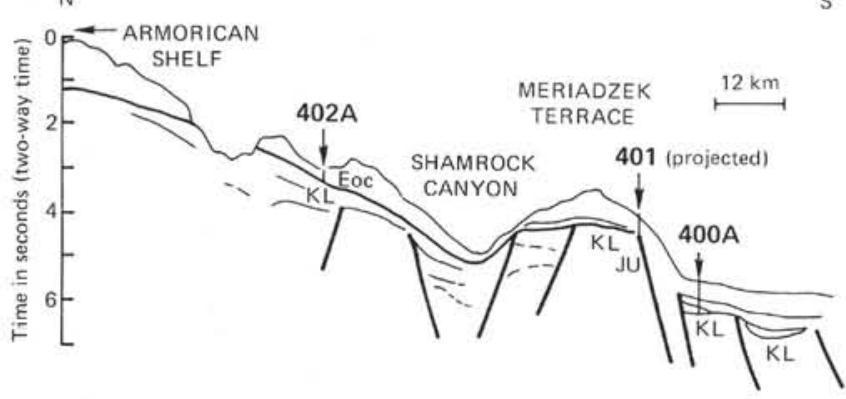

Figure 2. Topographic profile of continental margin across drill sites 400A, 401, and 402. coring to -89.5 meters produced oozes of Pleistocene age. Continuous coring started at -118 meters in nannofossil ooze of late Eocene age; the oldest Cenozoic sediments, at -137.5 meters were of middle Eocene age.

All age determinations are based upon both planktonic foraminifers and calcareous nannoplankton (see Site Summaries, this volume). The general stratigraphy and lithology is summarized in Figure 3.

Samples were selected, where possible, to represent intervals of not less than one million and no more than two million years. The samples, usually of $20 \mathrm{cc}$ volume, were disaggregated in a weak Calgon solution and washed on nested screens of $63 \mu \mathrm{m}$ and $125 \mu \mathrm{m}$ average openings. The residues were dried at room temperature so that the foraminifers would remain suitable for subsequent oxygen isotope analysis. Although the fine fraction also contained foraminifers, only the $>125 \mu \mathrm{m}$ fraction was searched (exhaustively) for benthic foraminifer specimens. In order to obtain representative species distributions, it was attempted to treat samples of sufficient size to yield about 300 specimens. Most of the 20 -cc samples provided from 200 to 400 or even 500 specimens. Only a few samples from the Miocene of Hole 400A, of which the coarse fraction consisted almost exclusively of sponge spicules, yielded less than 200 specimens.

The richness of the available samples in specimens and species of benthic foraminifers was overwhelming. Of the 54 samples selected for study, only 39 were completely analyzed. Over 450 species were separated from this material, but because of existing time and literature constraints, about 150 of those had to be left in open nomenclature. The greatest effort went into the complete taxonomic assessment of the Paleogene faunas, therefore only they were systematically catalogued and the hundred most common and significant species illustrated. The taxonomy and biostratigraphy of the Neogene species could not be completed for inclusion into this volume. However, the census data for the Neogene species were incorporated into the quantitative faunal analyses.

\section{PRESERVATION}

The state of preservation of the benthic foraminiferal tests is a function of several factors. Syndepositional carbonate dissolution appears to be the dominant of these. As a general rule, benthic foraminiferal tests are more resistant to dissolution than tests of planktonic foraminifers (Parker and Berger, 1971) so that an increase of the proportion of benthic specimens in the total population can be taken as a measure of the degree of dissolution that the sample suffered. Samples from the shallower sites $(401,402)$ rarely contained more than 1 per cent benthic specimens, whereas most of the samples from the deep site (Hole 400A) contained more than 1 per cent (up to $85 \%$ ) benthic specimens (Figure 4). Apparently, through much of the Cenozoic (from the middle Eocene to the early Pliocene) Hole 400A must have been near or below the foraminiferal carbonate compensation depth. The degree of damage suffered by the benthic foraminiferal tests corresponded closely to this indicator of the degree of carbonate dissolution. The first sign of damage is the loss of surface smoothness (shine) and the transparency of certain hyaline species. An increase in the incidence of physical damage 


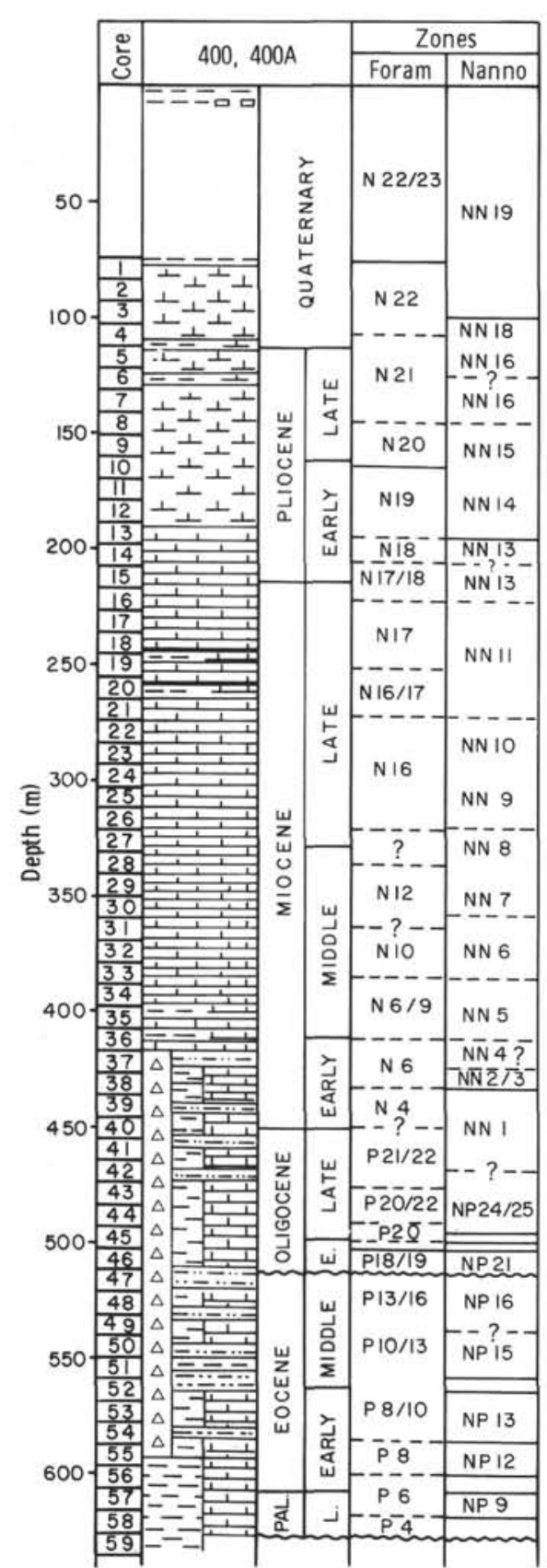

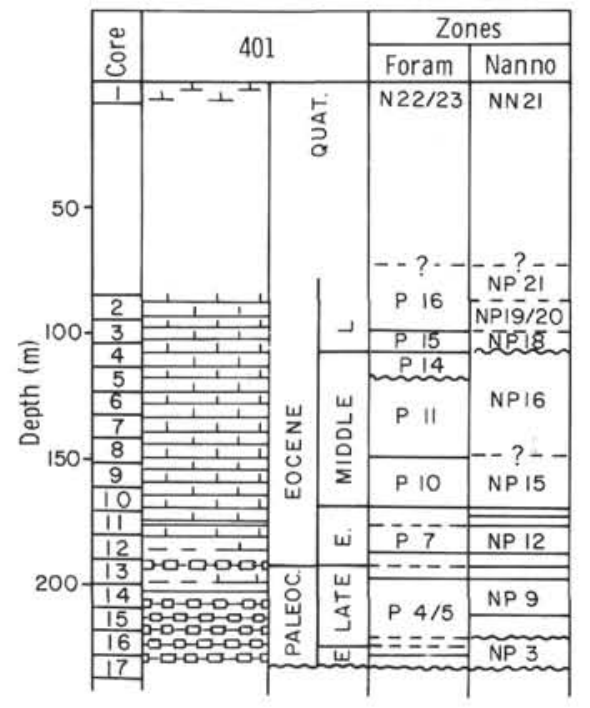

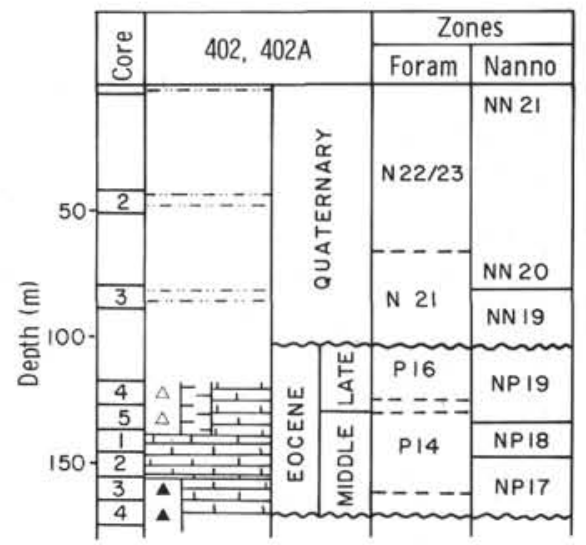

Figure 3. Generalized biostratigraphy and lithology of Holes 400A, 401, and 402.

follows: breakage of the last chamber(s) of enrolled specimens, puncture of chamber walls, breakage of rectilinear specimens, and damage of ornamentations and apertural features. As many as $35 \%$ of the benthic specimens may be more or less severely damaged in those samples where benthics comprise more than 20 to 25 per cent of the total foraminiferal fauna.

Preservation is only to a limited degree a function of geologic age. Whereas practically all Holocene benthic specimens were shiny and transparent, few were so in samples older than early Pleistocene. But exceptions occur: many Paleocene samples from Hole 400A and Site 401 contained benthic foraminiferal faunas which were as undamaged, shiny, and transparent as any of the Holocene faunas.
Tests with a sugary appearance, because of calcite overgrowth, occurred in some samples where diagenesis had transformed the calcareous ooze into chalk. Their occurrence was not systematically correlated with geologic age or the severity of syndepositional dissolution.

Signs of predation (Sliter, 1971) were observed on specimens of all ages, but the incidence of predation, although not checked systematically, remained well below that which was observed by Douglas (1973). Rarely more than four or five bored specimens per sample were found.

\section{COMPARATIVE MATERIAL}

In order to test the cosmopolitan nature of the faunas of the Bay of Biscay sites, and to obtain an independent check of the 

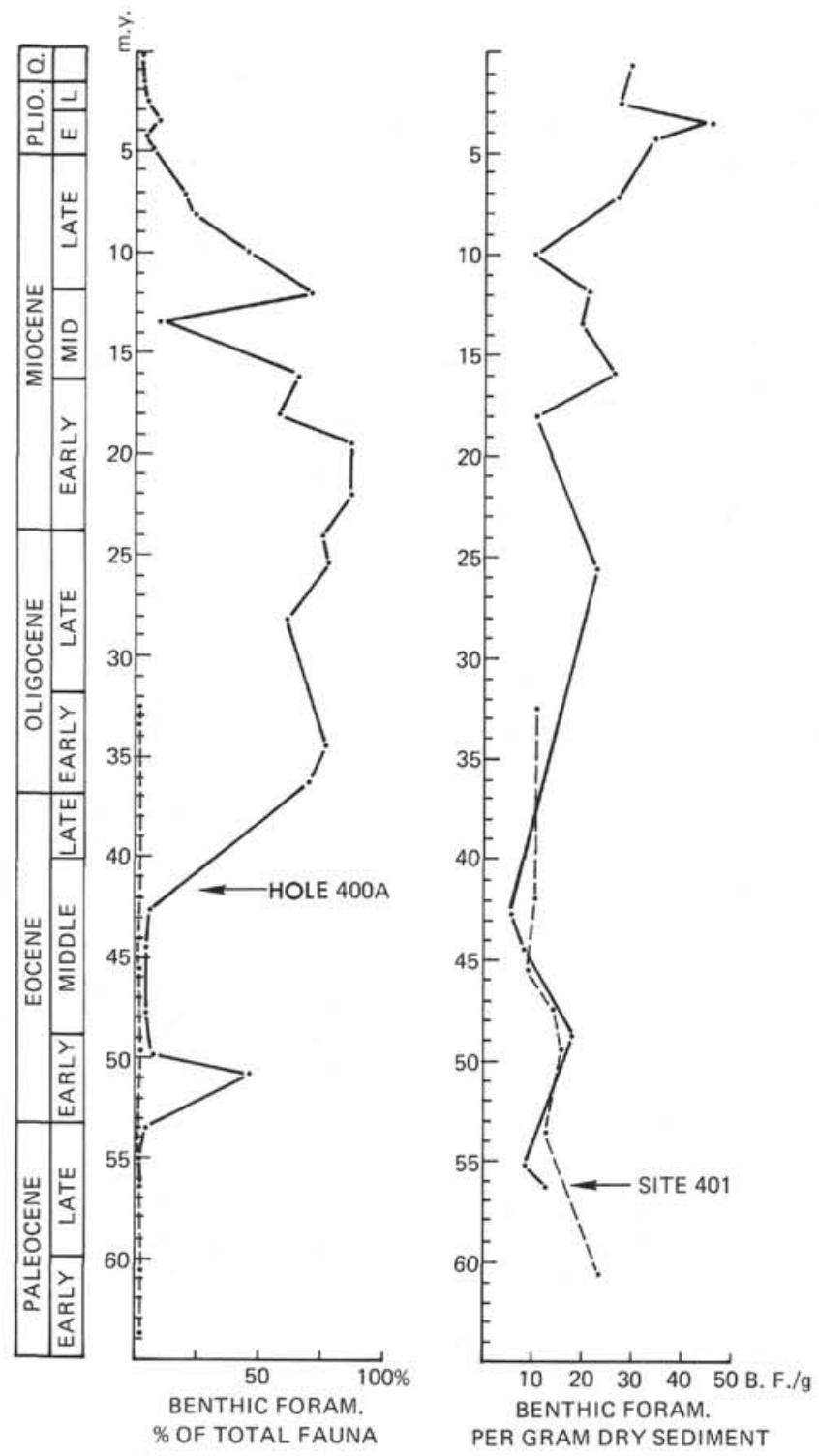

Figure 4. Abundance of benthic foraminfers in sediments of Hole $400 \mathrm{~A}$ and Site 401, expressed in percentage of total fauna and in specimens per gram of dry sediments.

paleobathymetric estimates, 12 Paleogene samples from various sites of DSDP Legs 3 and 12 were analyzed and the results were compared with the results of the faunal analysis of the Leg 48 Bay of Biscay sites.

\section{SPECIES ABUNDANCE}

Most samples, regardless of age, contained between 40 and 60 species of benthic foraminifers. Samples which had suffered the most severe carbonate dissolution yielded fewer species, 25 per sample being the minimum. Because of the usual strong dominance by one or two species in each sample, a fact also observed by Douglas (1973), many species are represented by only one or two specimens per sample. Their value as stratigraphic markers is thus sharply reduced in small samples, although they may be among the most distinctive of the species.

\section{BIOSTRATIGRAPHY}

Tables 1 and 2 present the ranges of occurrence of named and common Paleogene benthic foraminiferal species within the samples from Hole 400A and Site 401. Most notable from the inspection of these charts is the observation that many species do not occur at both sites. Secondly, the ranges of species that are common to both sites are often not concurrent. This observation should serve to guard against too much confidence in the reliability of benthic foraminifers as stratigraphic index fossils. Although differences within the deepsea environment are minimal, the deep-sea organisms are very sensitive to them and their distributions vary accordingly (Schnitker, 1974; Streeter, 1973).

Despite this apparent influence of the biotope upon the stratigraphic occurrence of species, the ending and the beginning of many species ranges, at both sites, at the Paleocene-Eocene boundary, at the base of the Oligocene, and within the earliest Miocene, permit at least the recognition of these major geologic age boundaries. Exploiting the finer detail of the observed species ranges for the establishment of a biostratigraphic zonation scheme analogous to that in existence for planktonic microfossils would be premature until the effects of environmental influences upon the occurrence of species is better known.

\section{FAUNAL GROUPINGS}

Douglas (1973) in his analysis of benthic foraminifers from the central North Pacific points out that most of his more common benthic foraminiferal species could be placed into successive groups. Such division is also apparent among the species of Hole 400A and Site 401 (Tables 1 and 2). To investigate this relationship quantitatively, the census data of all Paleogene samples of Hole $400 \mathrm{~A}$ and Site 401 were submitted to a hierarchial cluster analysis (Williams, 1971). Canberra Metric correlation coefficients (Stephenson et al., 1972) were calculated because this method takes the abundance of species into account and is less sensitive to rare and sporadically occurring species than correlation coefficients based upon the presence/absence of species. Because of program constraints, only 100 species could be incorporated into this analysis. Only species which were represented in more than one sample or by more than two specimens per sample were selected. The results of this analysis, which arranged samples according to the degree of their faunal similarity, is shown in Figure 5. Confirming the previous qualitative statements, two facts are brought out clearly by the clustering dendogram:

1) Samples from Hole $400 \mathrm{~A}$ and Site 401 clustered separately, regardless of age.

2) Samples clustered into age groups.

The faunal dissimilarity between the samples from Hole $400 \mathrm{~A}$ and Site 401 serves to re-emphasize that even in the deep-sea environment, geologic age may be of lesser significance in determining the composition of a benthic fauna than environmental control.

Samples 400A-51-6, 93-96 cm and 401-9-6, 72-74 cm form an exception to the general observation because they cluster, but at a very low level of correlation. Both samples are of early middle Eocene age (Zone P.10). That the two samples are coeval suggests downslope contamination, a 
TABLE 1

Stratigraphic Occurrence of Common Species Within Hole 400A Samples

\begin{tabular}{|c|c|c|c|c|c|c|c|c|c|c|c|c|c|c|}
\hline \multirow{4}{*}{$\begin{array}{r}\text { EPOCH } \\
\text { P. F. ZONE } \\
\text { SAMPLE } \\
\end{array}$} & \multirow{2}{*}{\multicolumn{3}{|c|}{$\begin{array}{c}\text { PALEOCENE } \\
\text { LATE } \\
\end{array}$}} & \multicolumn{6}{|c|}{ EOCENE } & \multicolumn{5}{|c|}{ OLIGOCENE } \\
\hline & & & & \multicolumn{3}{|c|}{ EARLY } & \multicolumn{3}{|c|}{ MIDDLE } & \multicolumn{2}{|c|}{ EARLY } & \multicolumn{3}{|c|}{ LATE } \\
\hline & $\mathrm{P} .4$ & P.5 & P.6 & P.6 & P.8 & P.9 & \begin{tabular}{|l|l|} 
P.10 \\
\end{tabular} & \begin{tabular}{l|l} 
P.12 \\
\end{tabular} & P.13 & \begin{tabular}{l|l|} 
P.18 \\
\end{tabular} & P.19 & \begin{tabular}{l|l|l|} 
P.20 & \\
\end{tabular} & P.21 & P.22 \\
\hline & $59-1$ & $58, \mathrm{CC}$ & $57-2$ & $56-2$ & $55, \mathrm{CC}$ & $54, \mathrm{CC}$ & $51-6$ & $49-1$ & $46-6$ & $47-1$ & $45, \mathrm{CC}$ & $45-3$ & $45 \cdot 2$ & $44-1$ \\
\hline \multicolumn{15}{|l|}{ Alabamina dissonata } \\
\hline \multicolumn{15}{|l|}{ Allomorphinella sp. } \\
\hline \multicolumn{15}{|l|}{ Anomalinoides alazanensis } \\
\hline \multicolumn{15}{|l|}{ Anomalinoides pompilioides } \\
\hline Anomalinoides spissiformis & & & & & & & & & & & & & & \\
\hline Astrononion astrale & & & & & & & & & & & & & & \\
\hline Bulimina pupoides & & & & & & & & & & & & & & \\
\hline Bulimina semicostata & & & & & & & & & & & & & & \\
\hline Bulimina trinitatensis & & & & & & & & & & & & & & \\
\hline Chrysalogonium tenuicostatum & & & & & & & & & & & & & & \\
\hline Cibicidoides beckmanni & & & & & & & & & & & & & & \\
\hline Cibicidoides cookei & & & & & & & & & & & & & & \\
\hline Cibicidoides havanaensis & & & & & & & & & & & & & & \\
\hline Cibicidoides mexicana & & & & & & & & & & & & & & \\
\hline Cibicidoides pseudoungerianus & & & & & & & & & & & & & & \\
\hline Cibicidoides pseudowuellerstorfi & & & & & & & & & & & & & & \\
\hline Cibicidoides sinistralis & & & & & & & & & & & & & & \\
\hline Ellipsoglandulina exponens & & & & & & & & & & & & & & \\
\hline Ellipsoglandulina principiens & & & & & & & & & & & & & & \\
\hline Ellipsopolymorphina sp. & & & & & & & & & & & & & & \\
\hline Eponides abuillotensis & & & & & & & & & & & & & & \\
\hline Eponides subcandidulus & & & & & & & & & & & & & & \\
\hline Globocassidulina globosa & & & & & & & & & & & & & & \\
\hline Gyroidina girardana & & & & & & & & & & & & & & \\
\hline Gyroidinoides beisseli & & & & & & & & & & & & & & \\
\hline Gyroidinoides complanata & & & & & & & & & & & & & & \\
\hline Gyroidinoides octocamerata & & & & & & & & & & & & & & \\
\hline Gyroidinoides planulata & & & & & & & & & & & & & & \\
\hline Gryoidinoides sp. & & & & & & & & & & & & & & \\
\hline Leuticulina spp. & & & & & & & & & & & & & & \\
\hline Nonion havanaense & & & & & & & & & & & & & & \\
\hline Nuttallides truempyi & & & & & & & & & & & & & & \\
\hline Oridorsalis umbonatus & & & & & & & & & & & & & & \\
\hline Osangularia dominicana & & & & & & & & & & & & & & \\
\hline Osangularia mexicana & & & & & & & & & & & & & & \\
\hline Planulina ammophila & & & & & & & & & & & & & & \\
\hline Pleurostomella alternans & & & & & & & & & & & & & & \\
\hline Pleurostomella bierigi & & & & & & & & & & & & & & \\
\hline Pleurostomella incrassata & & & & & & & & & & & & & & \\
\hline Pleurostomella subcylindrica & & & & & & & & & & & & & & \\
\hline Praebulimina grata & & & & & & & & & & & & & & \\
\hline Praebulimina tarda & & & & & & & & & & & & & & \\
\hline Pullenia bulloides & & & & & & & & & & & & & & \\
\hline Pullenia quinqueloba & & & & & & & & & & & & & & \\
\hline Pullenia riveroi & & & & & & & & & & & & & & \\
\hline Quadrimorphina sp. 1 & & & & & & & & & & & & & & \\
\hline Quadrimorphina sp. 2 & & & & & & & & & & & & & & \\
\hline Quadrimorphina sp. 3 & & & & & & & & & & & & & & \\
\hline Stetsonia sp. cf. $S$. danvillensis & & & & & & & & & & & & & & \\
\hline Stilostomella aculeata & & & & & & & & & & & & & & \\
\hline Stilostomella decurta & & & & & & & & & & & & & & \\
\hline Stilostomella gracillima & & & & & & & & & & & & & & \\
\hline Heronallenia sp. & & & & & & & & & & & & & & \\
\hline Trifarina sp. & & & & & & & & & & & & & & \\
\hline Uvigerina spinicostata & & & & & & & & & & & & & & \\
\hline
\end{tabular}


TABLE 2

Stratigraphic Occurrence of Common Species Within Site 401 Samples

\begin{tabular}{|c|c|c|c|c|c|c|c|c|c|c|}
\hline \multirow{4}{*}{$\begin{array}{r}\text { EPOCH } \\
\text { P. F. ZONE } \\
\text { SAMPLE }\end{array}$} & \multicolumn{3}{|c|}{ PALEOCENE } & \multicolumn{7}{|c|}{ EOCENE } \\
\hline & \multicolumn{2}{|c|}{ EARLY } & \multirow{2}{*}{$\begin{array}{l}\text { L. } \\
\text { P.5 }\end{array}$} & \multicolumn{2}{|c|}{ EARLY } & \multicolumn{3}{|c|}{ MIDDLE } & \multicolumn{2}{|c|}{ LATE } \\
\hline & P.1 & P.2 & & P.6 & P.9 & P.10 & P.12 & P.13 & P.16 & P.17 \\
\hline & $17 . \mathrm{CC}$ & $16 . \mathrm{CC}$ & $14 . \mathrm{CC}$ & $13, \mathrm{CC}$ & 114 & $9 \cdot 6$ & 7.5 & $5-3$ & $4, \mathrm{CC}$ & 2.CC \\
\hline \multicolumn{11}{|l|}{ Anomalinoides praespissiformis } \\
\hline \multicolumn{11}{|l|}{ Anomalinoides spissiformis } \\
\hline \multicolumn{11}{|l|}{ Anomalinoides semicribrata } \\
\hline \multicolumn{11}{|l|}{ Aragonia anauna } \\
\hline \multicolumn{11}{|l|}{ Aragonia ouezzanensis } \\
\hline Aragonia velascoenis & & & & & & & & & & \\
\hline Bandyella beckmanni & & & & & & & & & & \\
\hline Bolivina daniensis & & & & & & & & & & \\
\hline Bulimina jarvisi & & & & & & & & & & \\
\hline Bulimina pupoides & & & & & & & & & & \\
\hline Bulimina semicostata & & & & & & & & & & \\
\hline Bulimina trinitatensis & & & & & & & & & & \\
\hline Bulimina tuxpamensis & & & & & & & & & & \\
\hline Cibicidoides haitensis & & & & & & & & & & \\
\hline Cibicidoides perlucidus & & & & & & & & & & \\
\hline Cibicidoides subcandidulus & & & & & & & & & & \\
\hline Cibicidoides sinistralis & & & & & & & & & & \\
\hline Ellipsoglandulina principiens & & & & & & & & & & \\
\hline Ellipsopolymorphina sp. & & & & & & & & & & \\
\hline Eponides hillebrandti & & & & & & & & & & \\
\hline Eponides subcandidulus & & & & & & & & & & \\
\hline Gavelinella beccariiformis & & & & & & & & & & \\
\hline Gavelinella micra & $=0$ & & & & & & & & & \\
\hline Globocassidulina globosa & & & & & & & & & & \\
\hline Gyroidina girardana & & & & & & & & & & \\
\hline Gyroidinoides beisseli & & & & & & & & & & \\
\hline Gyroidinoides complanata & & & & & & & & & & \\
\hline Gyroidinoides globosa & & & & & & & & & & \\
\hline Gyroidinoides sp. & & & & & & & & & & \\
\hline Lenticulina spp. & & & & & & & & & & \\
\hline Nodosarella acus & & & & & & & & & & \\
\hline Nodosarella subnodosa & & & & & & & & & & \\
\hline Nonion havanaense & & & & & & & & & & \\
\hline Nuttallides truempyi & & & & & & & & & & \\
\hline Ordorsalis umbonatus & & & & & & & & & & \\
\hline Orthomorphina rohri & & & & & & & & & & \\
\hline Osangularia dominicana & & & & & & & & & & \\
\hline Osangularia mexicana & & & & & & & & & & \\
\hline Osangularia plummerae & & & & & & & & & & \\
\hline Planulina renzi & & & & & & & & & & \\
\hline Pleurostomella alternans & & & & & & & & & & \\
\hline Pleurostomella bierigi & & & & & & & & & & \\
\hline Pleurostomella clavata & & & & & & & & & & \\
\hline Pleurostomella incrassata & & & & & & & & & & \\
\hline Pleurostomella subcylindrica & & & & & & & & & & \\
\hline Praebulimina grata & & & & & & & & & & \\
\hline Praebulimina tarda & & & & & & & & & & \\
\hline Pullenia coryelli & & & & & & & & & & \\
\hline Pullenia eocenica & & & & & & & & & & \\
\hline Pullenia quinqueloba & & & & & & & & & & \\
\hline Quadratobuliminella pyramidalis & & & & & & & & & & \\
\hline Quadrimorphina sp. 2 & & & & & & & & & & \\
\hline Quadrimorphina sp.3 & & & & & & & & & & \\
\hline Stilostomella aculeata & & & & & & & & & & \\
\hline Stilostomella gracillima & & & & & & & & & & \\
\hline Stilostomella plummerae & & & & & & & & & & \\
\hline Tappanina selmensis & & & & & & & & & & \\
\hline Urigerina spinicostata & & & & & & & & & & \\
\hline
\end{tabular}






Figure 5. Dendogram of faunal associations among Hole $400 \mathrm{~A}$ and Site 401 samples. The clusters are from left to right: Eocene, Hole 400A; Paleocene, Hole 400A; Eocene, Hole 400A and Site 401; Oligocene, Hole 400A; Eocene, Site 401; Paleocene Site 401.

suspicion enhanced because Sample 400A-51-6, 93-96 cm came from a chalk layer intercalated in a mud sequence.

The Paleocene sample clusters from both sites separated sharply from sample clusters of other ages. Paleocene marker species for Site 401 are: Anomalinoides praespissiformis, Aragonia ouezzanensis, Ellipsoglandulina principiens, Eponides hillebrandti, Gavelinella beccariiformis, Gyroidinoides globosa, Osangularia plummerae, and Pullenia coryelli. The following Paleocene marker species for Hole 400A are neither as common, nor as distinct as those for Site 401: Anomalinoides alazanensis, Bandyella beckmanni, and Pleurostomella incrassata. Gyroidinoides globosa is the only species which appears to be a Paleocene index species for both sites. The Paleocene-Eocene boundary at Site 401 is characterized principally by the extinction of taxa, whereas this boundary at Hole $400 \mathrm{~A}$ is best defined by the first occurrence of new species.

All samples of Eocene age from Site 401 clustered together, with the early Eocene samples forming one subcluster, and the middle and late Eocene samples forming another. The most notable species from the Eocene of Site 401 are: Anomalinoides semicribrata (a distinctive but very rare species), Bulimina jarvisi, Cibicidoides haitensis, Gyroidina girardana, Gyroidinoides complanata, Nodosarella subnodosa, Osangularia mexicana, Pleurostomella alternans, P. subcylindrica, Praebulimina tarda, Pullenia eocenica, and Quadrimorphina sp. 3.

At Hole 400A early and middle Eocene samples clustered together. No late Eocene sediments were encountered at this site. These samples clustered with some of the highest corre- lation values observed in this analysis. The high correlation is due to a high proportion of species which are restricted to this time interval. Some of the common species of this group are: Alabamina dissonata, (?) Allomorphinella sp., Aragonia capdevilensis, Cibicidoides beckmanni, Eponides subcandidulus, and Gyroidinoides beisseli.

The final cluster represents samples of Oligocene age from Hole 400A. These Oligocene faunas have very little in common with their Hole 400A Eocene predecessors and are characterized by the following species: Anomalinoides pompiliodes, Astrononoin australe, Bulimina semicostata, Cibicidoides cookei, C. mexicana, C. pseudowuellerstorfi, C. sinistralis, Stetsonia cf. danvillensis, Eponides abuillotensis, Osangularia mexicana, Pullenia bulloides, and Trifarina sp. Many additional species are also restricted to these Oligocene samples, but their sporadic occurrence does not warrant their inclusion in the above listing.

\section{EVOLUTION OF FAUNAL GROUPS}

The existence of distinct deep water faunal groups within the Paleogene samples, together with the fact that these groups did not persist through time raises the question as to whether there has been any direction to this faunal change. The term "direction"' is here applied in two senses:

1) "direction" of faunal evolution in terms of ancestry, and

2) "direction"' in habitat changes (depth or geography) The relationship between the primary clusters of the cluster dendogram (Figure 5) is an expression of faunal evolutionary changes. Figure 6 presents the clustering relationships of Figure 5 , ordered by site and stratigraphic occurrence.

The cluster of the Paleocene samples of Site 401 shows an exceedingly low correlation with any of the other clusters (=faunal groups). As can be seen on the range charts (Tables 1 and 2), most of the Paleocene species of Site 401 samples disappear at the end of the Paleocene. This group can thus be considered a "dead end.',

The cluster of the late Paleocene samples of Hole 400A correlates, albeit somewhat weakly, with the cluster of Eocene samples from the same site, indicating that only a relatively minor change took place within the very deep sea at the Paleocene-Eocene boundary. From the range chart it becomes clear that the late Paleocene very deep water species persisted into the Eocene and that the Eocene very deep water fauna acquired its distinction through the addition of new species. This combined cluster of Paleocene and Eocene samples does not show any further significant relationship to other clusters, thus indicating a further "dead end."

Most intriguing is the association of the cluster of Eocene Site 401 samples with the cluster of Oligocene Hole 400A samples. Many of the Eocene Site 401 species are part of the Oligocene Hole 400A fauna (Tables 1 and 2). The inevitable conclusion is that between the Eocene and the early Oligocene the endemic very deep water fauna became largely extinct and was replaced either by newly evolving species or by Eocene species from shallower water which migrated to greater depths.

\section{PALEOBATHYMETRY}

At least since the Challenger Expedition (Brady, 1884) it has been clear that the distribution of deep water benthic foraminifers is depth dependent. Phleger (1960) summarized 


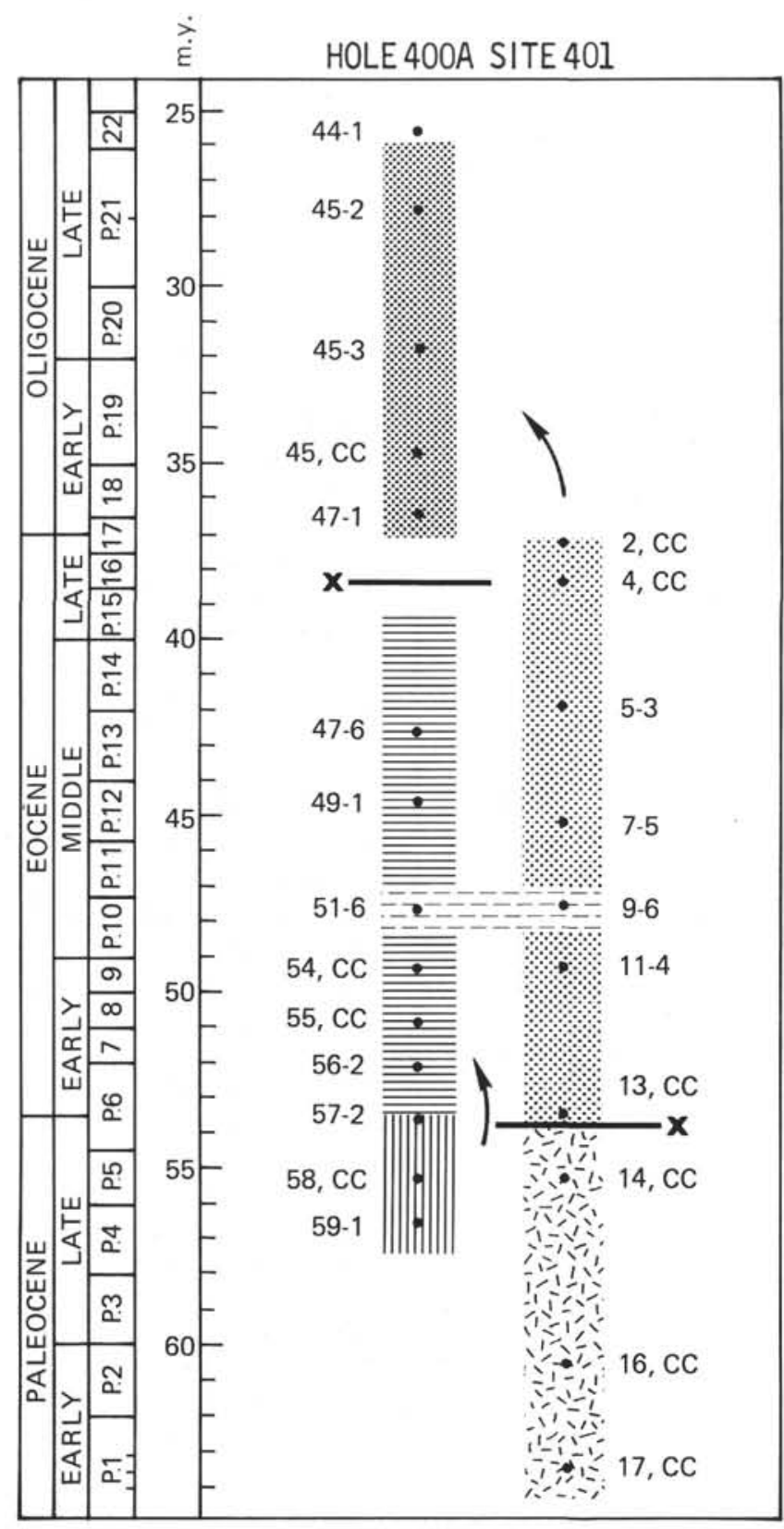

Figure 6. Faunal associations from Figure 5, arranged by site and stratigraphic sequence. Arrow indicates successive relationships, $\mathbf{x}$ indicates stratigraphic termination of faunal association.

the data on foraminiferal depth distribution which was available at that date. "Depth calibrations"' of this sort were applied to fossil faunas from late Neogene deposits which contain many species that are still present in modern seas. The studies by Natland (1933) and Bandy and Arnal (1969) exemplify this type of paleoecologic work. Studies of this kind are based on the assumptions that past species had the same depth preferences as their modern counterparts and that the habitat itself has not changed with time. The first assumption still appears to be valid for faunas of late Neogene age, but not for older faunas which have only few or no living counterparts. The second assumption was proven invalid by the studies of Schnitker (1974) and Streeter (1973) which have shown that major shifts in habitat occurred in the North Atlantic during the Pleistocene. Climatically induced changes of the deep oceanic water masses brought about rapid and drastic changes in the composition of the bottom faunas. During glacial periods the present-day abyssal foraminiferal faunas are replaced by faunas composed of species which presently reside nearly 2000 meters shallower, on the continental slopes or the Mid-Atlantic Ridge. During interglacial periods, the present-day abyssal foraminiferal fauna is re-established. Because glacially induced eustatic sea level change did not exceed 150 to 200 meters, it is obvious that factors other than depth are of primary importance in controlling the distribution of deep water benthic foraminifers.

Pliocene and Quaternary samples from Holes 400A, 401, and 402 could easily be categorized as having been deposited either during glacial or interglacial stages by the relative abundance of the coldwater species Globigerina pachyderma within the population of planktonic foraminifers. Samples from Hole 400A thus identified as Holocene or interglacial contained Epistominella exigua as dominant species with common Planulina wuellerstorfi, Oridorsalis umbonatus, Osangularia umbonifera, Melonis pompilioides, $M$. barleeanus, Pullenia bulloides, P. quinqueloba, Cibicidoides robertsonianus, $C$. bradyi, $C$. kullenbergi, and many other species of low abundance. Glacial stage samples contained Uvigerina peregrina as the dominant species, often constituting $>50 \%$ of all benthic foraminiferal specimens; in addition such upper continental slope species as Globobulimina subglobosa and Bulimina alazanensis occur. In the eastern Atlantic Uvigerina peregrina is an important species in samples from about 1200 meters depth (Streeter, 1973); in the western Atlantic it occurs commonly at around 1500 meters (personal observation). Care must thus be exercised in basing paleodepth estimates only upon interglacial samples. If diverging paleodepth estimates are obtained, samples with the deepest paleodepth estimate have the highest probability of being close to the true paleodepth.

From Site 401 only one sample from a Quaternary glacial stage was analyzed for its content of benthic foraminifers. The sample was dominated by Globobulimina turgida. Also present in significant numbers were Bulimina aculeata, $B$. inflata, Chilostomella oolina, Cibicidoides kullenbergi, Hoeglundina elegans, Melonis pompilioides, Oridorsalis umbonatus, Planulina wuellerstorfi, Pullenia quinqueloba, and a few Epistominella exigua. This assemblage is very similar to faunas reported by Pujos-Lamy (1975) from comparable depths in the southern Bay of Biscay.

Two samples from Site 402, one of glacial the other of interglacial Quaternary sediments, were analyzed. The faunas were both essentially identical to the one described for Site 401 , but with the addition of significant numbers ( $\sim 28 \%$ of the total) of shallow water species such as Cibicides lobatulus, several species of Elphidium, Gavelinopsis praegeri, and Planorbulina mediterranensis. These species are downslope contaminants. As can be seen on Figure 2, Site 402 is most accessible to downslope mass movement, whereas Hole 400A and Site 401 are not. The glacialinterglacial faunal contrast between these two samples manifested itself principally in a change of the relative abundance of species. In particular Cassidulina neocarinata became abundant in the glacial stage sample. 
Using the technique developed by Imbrie and Kipp (1971), a transfer function-paleoecological equation was derived from census data of benthic foraminifers from 98 North Atlantic surface sediment samples (Schnitker, unpublished). This paleoecological equation was used to make quantitative estimates of paleodepth for late Neogene samples from Holes $400 \mathrm{~A}, 401$, and 402 . Although this paleoecological equation is heavily based upon samples from the western North Atlantic and biased towards samples from greater than 2000 meters depth, the paleodepth estimates for samples from interglacial stages were close to the actual drilling depth of the respective sites:

\begin{tabular}{lcc}
\hline Sample & Estimate & Error \\
\hline $400 \mathrm{~A}-1-1,74-76 \mathrm{~cm}$ & $4125 \mathrm{~m}$ & $274 \mathrm{~m}$ \\
$400 \mathrm{~A} \cdot 14-3,22-24 \mathrm{~cm}$ & $3986 \mathrm{~m}$ & $413 \mathrm{~m}$ \\
$401-1-1,11-13 \mathrm{~cm}$ & $2115 \mathrm{~m}$ & $380 \mathrm{~m}$ \\
$402-2, \mathrm{CC}$ & $1976 \mathrm{~m}$ & $363 \mathrm{~m}$ \\
\hline
\end{tabular}

Paleodepth estimates for samples from glacial stages were grossly in error for Hole $400 \mathrm{~A}$ and still significantly so for Sites 401 and 402:

\begin{tabular}{lcr}
\hline Sample & Estimate & Error \\
\hline $400 \mathrm{~A}-2-2,78-80 \mathrm{~cm}$ & $2986 \mathrm{~m}$ & $1413 \mathrm{~m}$ \\
$400 \mathrm{~A}-5-1,86-88 \mathrm{~cm}$ & $2638 \mathrm{~m}$ & $1761 \mathrm{~m}$ \\
$400 \mathrm{~A}-10-1,57-59 \mathrm{~cm}$ & $3057 \mathrm{~m}$ & $1342 \mathrm{~m}$ \\
$400 \mathrm{~A}-16-1,143-145 \mathrm{~cm}$ & $3182 \mathrm{n}$ & $1217 \mathrm{~m}$ \\
$402-1, \mathrm{CC}$ & $1527 \mathrm{~m}$ & $817 \mathrm{~m}$ \\
\hline
\end{tabular}

As geologically older samples were analyzed, the communalities of the varimax factors became increasingly lower, indicating that the faunal data from the core samples had progressively lower resemblance to present-day surface samples. As Imbrie and Kipp (1971, p. 91) have pointed out, this progressively increasing error is probably a measure of evolution.

Paleodepth estimates based on total faunas which are older than the middle of the late Miocene become more and more tenuous as fewer and fewer extant species were found among the fossil faunas. More reliance has to be placed upon the presence and abundance of "indicator species" although this method has shortcomings as explained earlier. Thus, continued common occurrence of Globocassidulina subglobosa, Gyroidinoides altiformis, Melonis barleeanus, M. pompilioides, Oridorsalis umbonatus, Pullenia bulloides, and $P$. quinqueloba back into the middle and even into the early Miocene at Hole 400A strongly suggests that depth remained unchanged during this time interval.

Paleogene faunas are so unlike modern faunas that paleodepth estimates can no longer be based upon faunal or species comparisons. Some appreciation of paleodepth can be gained by the occurrence of certain genera (i.e., Oridorsalis, Pullenia, Stilostomella) which at the present time are exclusively represented by deep water species, or by general faunal aspects such as the ratio between benthic and planktonic foraminifers or species diversity. It has been found that early Paleogene benthic foraminiferal faunas fall into two major groups, the "Midway-Type" fauna and the
"Velasco-Type" fauna (Berggren and Aubert, 1975) which, from general geologic consideration, were determined to represent either shelf assemblages (Midway-Type) or deep water assemblages (Velasco-Type). These faunas are very distinctive and it is thus relatively easy to determine whether a fauna originated in deep water or not; but it is difficult to state how deep the water was. The Paleogene faunas of Holes $400 \mathrm{~A}, 401$, and 402 are of the Velasco-Type.

Independent paleodepth estimates for sites on oceanic crust can be obtained through "backtracking"' (Berger, 1972; Berger and Winterer, 1974). Mid Paleogene paleodepths were determined for South Atlantic DSDP Holes 14, 19, 20C, and North Atlantic DSDP Sites 111 and 119. Paleogene faunas from samples of those sites were then compared with the Paleogene faunas from Hole 400A and Site 401. These samples, with their actual sea-floor depth and paleodepth are listed in Table 3. The use of such "depth calibrated" faunas as a basis for comparative paleodepth estimates of coeval faunas from different localities assumes that no significant latitudinal (or geographic) faunal variations existed at that time. Although this was probably so, the point remains yet to be proven.

Running the census data of these additional samples through the cluster analysis together with the Hole 400A and Site 401 census data resulted in a disruption of the clustering sequence that was described earlier. Comparing the additional data one sample at a time with the Hole 400A and Site 401 data left the previous clustering intact with the additional sample joining one of the previously established groups ( $\mathrm{Ta}$ ble 4). The conclusions from this analysis are:

1) Time control is strong among Paleogene faunas of widely differing geographic origin, at least at the Epoch level.

2) The samples from shallow sites $(\sim 1800 \mathrm{~m}$ to $\sim 3000 \mathrm{~m}$ paleodepth) associated with coeval samples from Site 401 .

3) The samples from deep sites $(\sim 3100 \mathrm{~m}$ to $\sim 4200 \mathrm{~m}$ paleodepth) associated with coeval samples from Hole 400A.

4) The level of correlation increased as the paleodepth approached the actual depths of Hole 400A and Site 401. Thus, it is unlikely that the Cenozoic paleodepths of Hole $400 \mathrm{~A}$ and Site 401 differed much, if at all, from their actual depths.

Site 402 samples of Eocene age contained abundant shallow water species which are interpreted as being downslope contaminants, analogous to the contaminants observed in the Quaternary samples of Site 402. No quantitative analysis of this material was attempted. A qualitative assessment of the Velasco-Type species of Site 402 samples suggests that the faunas were similar to those of Site 401 and thus that Site 402 was probably at a similar paleodepth.

\section{FAUNAL CHANGE AND PALEOCEANOGRAPHY}

In this study the gradual morphologic change of a few species of benthic foraminifers could be observed from one sample to the next, giving insight into the pathways and rates by which the evolution of species progresses, but this fascinating aspect could not be pursued any further due to time constraints. However, the data at hand lend themselves to the study of the evolution of deep-sea faunas.

In a stable environment the need for adaptive change to external (environmental) pressure is very low. Evolutionary change proceeds slowly and randomly in response to general 
TABLE 3

Leg 3 and Leg 12 Backtracking Paleodepths

\begin{tabular}{|c|c|c|c|}
\hline Sample & Age & $\begin{array}{c}\text { Actual } \\
\text { Depth (m) }\end{array}$ & Paleodepth (m) \\
\hline $14-4-1$ & Late Oligocene & 4346 & $\sim 3600$ \\
\hline $14-6-3$ & Late Oligocene & 4346 & $\sim 3600$ \\
\hline $14-9-6$ & Late Eocene & 4346 & $\sim 3500$ \\
\hline $19-3-5$ & Late Oligocene & 4685 & $\sim 4200$ \\
\hline $19-10-6$ & Middle Eocene & 4685 & $\sim 4100$ \\
\hline $20 \mathrm{C}-1-5$ & Late Oligocene & 4506 & $\sim 3100$ \\
\hline $20 \mathrm{C}-4-4$ & Middle Eocene & 4506 & $\sim 3000$ \\
\hline $20 C-5-5$ & Early Eocene & 4506 & $\sim 3000$ \\
\hline $20 C-6-4$ & Early Paleocene & 4506 & $\sim 2900$ \\
\hline $119-16-4$ & Late Oligocene & 4447 & $\sim 3600$ \\
\hline $119-21-2$ & Middle Eocene & 4447 & $\sim 3500$ \\
\hline $111-6-3,111 \mathrm{~cm}$ & Middle Eocene & 1797 & $\sim 1800^{\mathrm{a}^{*}}$ \\
\hline
\end{tabular}

aDepth estimate by Berggren and Aubert, 1976.

selective (internal) pressures. Greater than average rates of faunal change may thus be interpreted as having been caused by instabilities of the environment.

No two adjacent samples ever had exactly the same species composition. Species were appearing, waxing, and waning in their abundance and eventually disappearing in the succession of samples. These changes did not occur randomly but were concentrated into relatively short time intervals with the intervening periods manifesting slow rates of change. This uneven rate of faunal change is the basis of the biostratigraphy, discussed earlier.

The correlation coefficients between adjacent samples can be regarded as an inverse measure of faunal turnover or evolution: the higher the correlation coefficient, the greater the faunal similarity between those samples, and the lower the degree of faunal turnover. Figure 7 shows the successive correlation coefficients between Paleogene samples of Hole $400 \mathrm{~A}$, normalized for the elapsed time between those samples. Peaks of faunal turnover occurred at the PaleoceneEocene boundary, at the Eocene/Oligocene boundary and, to a lesser extent, at the Oligocene/Miocene boundary. Times of great faunal stability were the middle and probably the late Eocene and also the middle Oligocene. The late Eocene hiatus unfortunately obscures the exact position of the faunal change between the Eocene and Oligocene.
Varimax factor analysis (Imbrie and Kipp, 1971) was used to resolve the census data of 200 common Cenozoic species from samples of Hole $400 \mathrm{~A}$ in terms of statistically independent groups, or faunal assemblages. The analysis produced six assemblages which together accounted for $88 \%$ of the original data. It is clear from Figure 8 that these assemblages represent the evolutionary faunal succession in Hole 400A:

1) a Paleocene assemblage (factor 4)

2) an Eocene assemblage (factor 2)

3) an Oligocene assemblage (factor 5)

4) an early and middle Miocene assemblage (factor 6)

5) a late Miocene to Holocene assemblage (factor 1)

6) a late Miocene to Pleistocene assemblage (factor 3)

The separation and sequence of the Paleogene faunal groupings coincide precisely with the grouping of samples produced by the cluster analysis. The early to mid Miocene assemblage is poorly defined and of relatively low significance. The late Neogene assemblage no. 1 assumes significance early in the late Miocene. The late Neogene assemblage no. 2 first assumes significance in the latest Miocene (400A-16-1), then increases to a maximum in the Pleistocene (400A-2-2). Intercalated in this sequence are two high values for the late Neogene assemblage no. 1, during the Pliocene (400A-14-3) and Holocene (400A-1-1). The samples that contain the late Neogene assemblage no. 1 contain an interglacial type benthic foraminiferal fauna; those representing the late Neogene assemblage no. 2 contain a glacialtype benthic foraminiferal fauna.

This succession of faunas at Hole $400 \mathrm{~A}$ and the varying rates of faunal evolution serve to emphasize that the deep-sea environment underwent important changes which were accomplished during relatively short time intervals. Because deep water is essentially a high latitude product, a comparison of the timing and magnitude of plate tectonic, climatic, and oceanographic events in these areas with the timing and magnitude of changes at Hole 400A permits deductions as to the nature of the deep-sea environmental changes that caused the faunal changes. Except for the late Neogene, it is not possible to deduce from the fossil data what the qualities of the past deep-sea environment have been, nor the nature of the changes that took place. But paleotemperature estimates based upon oxygen isotope measurements of deep-sea benthic foraminifers indicate that most of the changes in

TABLE 4

Correlations Between Leg 3 and Leg 12 Benthic Foraminiferal Faunas and Leg 48 Faunal Associations

\begin{tabular}{llclc}
\hline Sample & \multicolumn{1}{c}{ Age } & Paleodepth $(\mathrm{m})$ & \multicolumn{1}{c}{ Cluster } & $\begin{array}{c}\text { Level } \\
\text { of } \\
\text { Correlation }\end{array}$ \\
\hline $111-6-3$ & Middle Eocene & $\sim 1800$ & Eocene Site 401 & Very high \\
$20 \mathrm{C}-6-4$ & Early Paleocene & $\sim 2900$ & Paleocene Site 401 & High \\
$20 \mathrm{C}-5-5$ & Early Eocene & $\sim 3000$ & Eocene Site 401 & Low \\
$20 \mathrm{C}-4-4$ & Middle Eocene & $\sim 3000$ & Eocene Site 401 & Low \\
20 C-1-5 & Late Oligocene & $\sim 3100$ & Oligocene Hole 400A & Low \\
$14-9-6$ & Late Eocene & $\sim 3500$ & Eocene Hole 400A & Low \\
$119-21-2$ & Middle Eocene & $\sim 3500$ & Eocene Hole 400A & Medium \\
$14-6-3$ & Early Oligocene & $\sim 3600$ & Oligocene Hole 400A & Medium \\
$14-4-1$ & Late Oligocene & $\sim 3600$ & Oligocene Hole 400A & Medium \\
$119-16-4$ & Late Oligocene & $\sim 3600$ & Oligocene Hole 400A & Medium \\
$19-10-6$ & Middle Eocene & $\sim 4100$ & Eocene Hole 400A & High \\
$19-3-5$ & Late Oligocene & $\sim 4200$ & Oligocene Hole 400A & High \\
\hline
\end{tabular}






Figure 7. Rate of faunal turnover, expressed as the inverse of the time adjusted coefficient of correlation between adjacent samples.

benthic faunas correlate well with changes in bottom-water temperatures (Douglas and Savin, 1973; Savin et al., 1975; Shackleton and Kennett, 1975; Grazzini, et al., this volume). According to these measurements the Cenozoic deep sea has been characterized by declining temperatures.

The great faunal change near the Paleocene/Eocene boundary is not matched by a paleotemperature change of significant magnitude. The faunal turnover which characterizes the Eocene-Oligocene boundary is accompanied, and probably caused by, a rapid and severe temperature drop. This is the time when the separation of Australia and Antarctica permitted the establishment of the circum Antarctic cur-



Figure 8. Cenozoic faunal assemblage variation, Hole 400A. Arranged in stratigraphic order of appearance, note changes of scales. The reciprocal abundance variations of factors 1 and 3 (interglacial and glacial assemblages) are due to randomness of core sampling and do not represent a glacial-interglacial cycle.

rent system and when the initial Antarctic glaciation occurred (Kennett et al., 1972, 1974). Slight warming of the bottom water during the early Miocene was probably responsible for the differentiation of the Oligocene faunas from early and middle Miocene faunas. Bottom temperatures dropped abruptly again near the end of the middle Miocene, a time when the late Neogene bottom fauna came into existence. Two events could be responsible for this change: the continental ice cover of Antarctica reached sea level (Shackleton and Kennett, 1975), and/or the Iceland-Faroe ridge subsided sufficiently to link the Norwegian Sea and Arctic Ocean to the Atlantic thermohaline circulation regime, thus essentially establishing the present deep oceanic circulation pattern. Unfortunately, DSDP Leg 38 (Talwani, Udintsev, et al., 1976) results do not allow the dating of this subsidence. Miocene and Pliocene sediments were not encountered at Sites 352 and 336. A further cooling event during the Pliocene finds its possible expression in a more pronounced differentiation between the two late Neogene assemblages, which probably coincides with the onset of Northern Hemisphere continental glaciation, three m.y. ago (Berggren, 1972 a , b). Paleotemperature cycles were observed by Savin et al. (1975) on material as old as the early Miocene, but glacial-interglacial type faunal cycles were not apparent before the late Miocene at Hole 400A. Although the temperature differential between surface and bottom waters in the early Cenozoic was small, depth stratification of faunas was well established, suggesting that the ocean waters have been structured throughout Cenozoic time. 


\section{ACKNOWLEDGMENTS}

I wish to thank Drs. T. Kellogg and L. Watling who have kindly read the manuscript and suggested improvements. Dr. R.C. Tjalsma provided information and literature concerning Paleogene foraminiferal taxonomy. The assistance of C. Johnson in sample preparation and scanning electron microscopy is greatly appreciated. Financial support for the scanning electron photomicrographs was provided by the Faculty Research Fund of the University of Maine, Orono. This represents Contribution No. 105 of the Ira C. Darling Center, University of Maine at Orono.

\section{REFERENCES}

Bandy, O.L. and Arnal, R.E., 1969. Middle Tertiary basin development, San Joaquin Valley, California, Geol. Soc. Am. Bull., v. 80, p. $783-820$.

Berger, W.H., 1972. Deep sea carbonates: Dissolution facies and age-depth constancy, Nature, v. 236, p. 392-394.

Berger, W.H. and Winterer, E.L., 1974. Plate stratigraphy and the fluctuating carbonate line. In Hsü, K.J. and Jenkyns, H.C. (Eds.), Pelagic sediments on land and under the sea: Spec. Publ. Int. Ass. Sediment., v. 1, p. 11-48.

Berggren, W.A., 1972a. Cenozoic biostratigraphy and paleobiogeography of the North Atlantic. In Laughton, A.S., Berggren, W.A., et al. Initial Reports of the Deep Sea Drilling Project, v. 12: Washington (U.S. Government Printing Office), p. 965-1002.

1972b. Late Pliocene-Pleistocene glaciation. In Laughton, A.S., Berggren, W.A., et al., Initial Reports of the Deep Sea Drilling Project, v. 12: Washington (U.S. Government Printing Office), p. 953-963.

Berggren, W.A. and Aubert, J., 1975. Paleocene benthonic foraminiferal biostratigraphy, paleobiogeography and paleoecology of Atlantic-Tethyan regions: Midway-Type fauna, Paleogeog., Paleoclimatol., Paleoecol., v. 18, p. 72-192. 1976. Eocene benthonic foraminiferal biostratigraphy and paleobathymetry of Orphan Knoll (Labrador Sea), Micropaleontology, v. 22 , p. $327-346$.

Brady, H.B., 1884. Report on the foraminifera dredged by H.M.S. Challenger, during the years 1872-1876,Rept. Scientific Results of the Voyage of H.M.S. Challenger, (Zoology), v. 9, p. 1-814.

Douglas, R.G., 1973. Benthonic foraminiferal biostratigraphy in the central North Pacific, Leg 17, Deep Sea Drilling Project. In Winterer, E.L., Ewing, J.I., et al., Initial Reports of the Deep Sea Drilling Project, v. 17: Washington (U.S. Government Printing Office), p. 607-671.

Douglas, R.G. and Savin, S.M. 1973. Oxygen and carbon isotope analyses of Cretaceous and Teriary foraminifera from the central North Pacific. In Winterer, E.L., Ewing, J.I., et al., Initial Reports of the Deep Sea Drilling Project, v. 17: Washington (U.S. Government Printing Office), p. 591-605.

Imbrie, J. and Kipp, N.G., 1971. A new micropaleontological method for quantitative paleoclimatology: Application to a late Pleistocene Caribbean core. In Turekian, K.K. (Ed.), The Late Cenozoic glacial ages: New Haven (Yale Univ. Press), p. 71181.

Kennett, J.P., Burns, R.E., Andrews, J.E., Churkin, N., Davies, T.A., Dumitrica, P., Edwards, A.R., Galehouse, J.S., Packham, G.H., and van der Lingen, G.J., 1972. AustralianAntarctic continental drift, paleocirculation changes, and Oligocene deep-sea erosion, Nature Phys. Sci., v. 239, p. 51-55.

Kennett, J.P., Houtz, R.E., Andrews, P.B., Edwards, A.R., Gostin, V.A., Hajos, M., Hampton, M.S., Jenkins, D.G., Mar- golis, S.V., Ovenshine, A.T., and Perch-Nielsen, K., 1974. Development of the Circum-Antarctic Current, Science, v. 186, p. 144-147.

Natland, M.L., 1933. Temperature and depth classification of some Recent and fossil foraminifera in the southern California region, Univ. California, Scripps Inst. Oceanogr., Bull., Tech. Ser., p. 225-230.

Parker, F.L. and Berger, W.H., 1971. Faunal and solution patterns of planktonic foraminifera in surface sediments of the South Pacific, Deep-Sea Res., v. 18, p. 73-107.

Phleger, F.B., 1960. Ecology and distribution of Recent foraminifera: Baltimore, (Johns Hopkins Press).

Pujos-Lamy, A., 1975. Répartition bathymetrique des foraminifères benthiques profonds du Golfe de Gascogne avec d'autres aires océaniques, Rev. Espanola Micropal., v. 5, p. 213-234.

Savin, S.M., Douglas, R.G., and Stehli, F.G., 1975. Tertiary marine paleotemperatures, Geol. Soc. Am. Bull., v. 86, p. 1499-1510.

Schnitker, D., 1974. West Atlantic abyssal circulation during the past 120,000 years, Nature, v. 248, p. 385-387.

Shackleton, N.J., and Kennett, J.P., 1975. Paleotemperature history of the Cenozoic and the initiation of Antarctic glaciation: Oxygen and Carbon isotope analyses in DSDP Sites 277, 279, and 281. In Kennett, J.P., Houtz, R.E., et al., Initial Reports of the Deep Sea Drilling Project, v. 29: Washington (U.S. Government Printing Office), p. 743-760.

Sliter, W.V., 1971. Predation of benthic foraminifera, J. Foram. Res., v. 1, p. 20-29.

Stephenson, W., Williams, W.T., and Cook, S.D., 1972. Computer analyses of Peterson's original data on bottom communities, Ecol. Monogr., v. 42, p. 387-415.

Streeter, S.S., 1973. Bottom water and benthonic foraminifera in the North-Atlantic-Glacial-interglacial contrasts, Quat.Res., v. 3, p. 131-141.

Talwani, M., Udintsev, G., et al., 1976.Initial Reports of the Deep Sea Drilling Project, v. 38: Washington (U.S. Government Printing Office).

Williams, W.T., 1971. Principles of clustering, Ann. Rev. Ecol. Systematics, v. 2, p. 303-326.

Worthington, L.W. and Wright, W.R., 1970. North Atlantic Ocean atlas of potential temperature and salinity in the deep water, including temperature, salinity and oxygen profiles from the Erika Dan cruise of 1962, Woods Hole Oceanogr. Inst. Atlas Series II. p. 1-24.

\section{SELECTED ADDITIONAL REFERENCES}

Beckmann, J.P., 1953. Die Foraminiferen der Oceanic Formation (Eocaen-Oligocaen) von Barbados, Kl. Antillen, Eclog. Geol. Helv., v. 46, p. 301-412.

Bermudez, P.J., 1949. Tertiary smaller foraminifera of the Dominican Republic, Cushman Lab. Foram.Res., Spec. Publ., v. 25 , p. 1-322.

Bermudez, P.J. and Gamez, H.A. 1966. Estudio paleontologico de una seccion del Eoceno, Mem. Soc. Cienc. Nat. LaSalle, v. 26, p. 205-259.

Braga, G., De Biase, R., Grünig, A., and Proto Decima, F., 1975. Foraminiferi bentonici del Paleocene ed Eocene della sezione di Possagno, Schweiz. Pal. Abh., v. 97, p. 85-110, 187-199.

Cushman, J.A., 1926. The foraminifera of the Velasco Shale of the Tampico embayment, Am. Assoc. Petrol. Geol. Bull., v. 10, p. 581-612.

Cushman, J.A. and Jarvis, P.W., 1932. Upper Cretaceous foraminifera from Trinidad U.S. Nat. Mus., Proc., v. 80, p. $1-60$. 
Cushman, J.A. and Renz, H.H., 1946. The foraminiferal fauna of the Lizard Springs formation of Trinidad, B.W.I., Cushman Lab. Foram. Res., Spec. Publ., v. 18, p. 1-48. , 1948. Eocene foraminifera of the Navet and Hospital Hill formations of Trinidad, B.W.I., Cushman Lab. Foram. Res., Spec. Publ., v. 24, p. 1-42.

Hillebrandt, A., 1962. Das Paläozän und seine Foraminiferenfauna im Becken von Reichenhall und Salzburg, Bayer. Akad. Wiss., math.-natw. Cl. Abh., (N.F.), v. 108, p. 1-182.

Nuttall, W.L.F., 1930. Eocene foraminifera from Mexico, $J$. Paleontol., v. 4, p. 271-293.

,1932. Lower Oligocene foraminifera from Mexico, $J$. Paleontol., v. 6, p. 3-45.
Parker, F.L., and Bermudez, P.J., 1937. Eocene species of the genera Bulimina and Buliminella from Cuba, J. Paleontol., v. 11 , p. $513-516$.

Proto Decima, F. and Bolli, H.M., in press. Southeast Atlantic DSDP Leg 40 Paleogene benthonic foraminifers. In Bolli, H.M., Ryan, W.B.F., et al., Initial Reports of the Deep Sea Drilling Project, v. 40: Washington (U.S. Government Printing Office), p. 571-634.

White, M.P., 1928-1929. Some index foraminifera of the Tampico Embayment area of Mexico, J. Paleontol., v. 2, p. 177-215, $280-317$; v. 3 , p. $30-58$. 


\section{PLATE 1}

Figures 1, 2 Chrysalogonium longicostatum Cushman and Jarvis, 1934, Cushman Lab. Foram. Res., Contrib., v. 10, p. 74, pl. 10, fig. 12. Sample 401-7-5, 87-91 cm. Length of specimen $1.96 \mathrm{~mm}$.

Figures 3, 4 Chrysalogonium tenuicostatum Cushman and Bermudez, 1936, Cushman Lab. Foram. Res., Contrib., v. 12, p. 27, pl. 5, fig. 3-5. Sample 401-13, CC. Length of specimen $1.16 \mathrm{~mm}$.

Figure 5 Dentalina sp., cf. D. mucronata Neugeboren, 1856, K. Akad, Wiss., math.naturw. C1., v. 12 , pt. 2 , p. 83 , pl. 3, fig. 8-11. Sample 401-16, CC. Length of specimen $0.85 \mathrm{~mm}$.

Figure 6 Orthomorphina rohri (Cushman and Stainforth). Nodogenerina rohri Cushman and Stainforth, 1945, Cushman Lab. Foram. Res., Spec. Publ., v. 14, p. 39, pl. 5, fig. 26. Sample 401-13, CC. Length of specimen $0.78 \mathrm{~mm}$.

Figures 7, 8 Lenticulina sp. Sample 401-2, CC. Maximum diameter $0.26 \mathrm{~mm}$.

Figure 9 Polymorphina sp. Sample 401-9-6, 72-74 cm. Length of specimen $0.48 \mathrm{~mm}$.

Figure 10 Pyrulinoides acuminatus (Orbigny). Pyrulina acuminata Orbigny, 1840, Mem. Soc. Geol. France, v. 4, no. 1, p. 43, pl. 4, fig. 18, 19. Sample 401-17, CC. Length of specimen $0.44 \mathrm{~mm}$.

Figure 11 Praebulimina grata (Parker and Bermudez). Buliminella grata Parker and Bermudez, 1937, J. Paleontol., v. 11, p. 515, pl. 59, fig. 6. Sample 401-9-6, 72-74 $\mathrm{cm}$. Length of specimen $0.43 \mathrm{~mm}$.

Figures 12, 13, Quadratobuliminella pyramidalis de Klasz, 1953, Neues Jahrb. Geol. Pal., no. 10, 19 p. 435 , pl. $1,2$.

12, 13. From Sample 401-11-4, 95-97 cm presents "alate" form of species. Length of specimen $0.31 \mathrm{~mm}$.

19. From Sample 401-17, CC presents rounded form of species. Length of specimen $0.28 \mathrm{~mm}$.

Figures 14, 15 Praebulimina beaumonti (Cushman and Renz). Buliminella beaumonti Cushman and Renz, 1946, Cushman Lab. Foram. Res., Spec. Publ., v. 18, p. 36, pl. 6, fig. 7. Sample 401-13, CC. Length of specimen $0.43 \mathrm{~mm}$.

Figure 16 Praebulimina grata spinosa (Parker and Bermudez). Bulimina grata Parker and Bermudez var. spinosa Parker and Bermudez, 1937, J. Paleontol., v. 11, p. 516, pl. 59 , fig. 7. Sample 400A-58, CC. Length of specimen $0.24 \mathrm{~mm}$.

Figure 17 Praebulimina mendezensis (White). Bulimina mendezensis White, 1929, J. Paleontol., v. 3, p. 49, pl. 5, fig. 10. Sample 401-16, CC. Length of specimen $0.26 \mathrm{~mm}$.

Figure 18 Praebulimina tarda (Parker and Bermudez). Bulimina tarda Parker and Bermudez, 1937, J. Paleontol., v. 11, p. 514, pl. 58. fig. 6. Sample 400A-59-1, 5-7 cm. Length of specimen $0.23 \mathrm{~mm}$.

Figure 20 Bolivina sp. Sample 402-5, CC. Length of specimen $0.32 \mathrm{~mm}$.

Figures 21, 22 Bolivina daniensis (Wicher). Aragonia daniensis Wicher, 1956, Pal. Z., v. 30, p. 109, pl. 13, fig. 16. Sample 401-17, CC. Length of specimen $0.33 \mathrm{~mm}$.

Figures 23, 24 Bolivina hebes Macfayden, 1930, Geol. Soc. Egypt, p. 59, pl. 2, fig. 5. Sample $400 \mathrm{~A}-45, \mathrm{CC}$. Length of specimen $0.24 \mathrm{~mm}$. 


\section{PLATE 1}
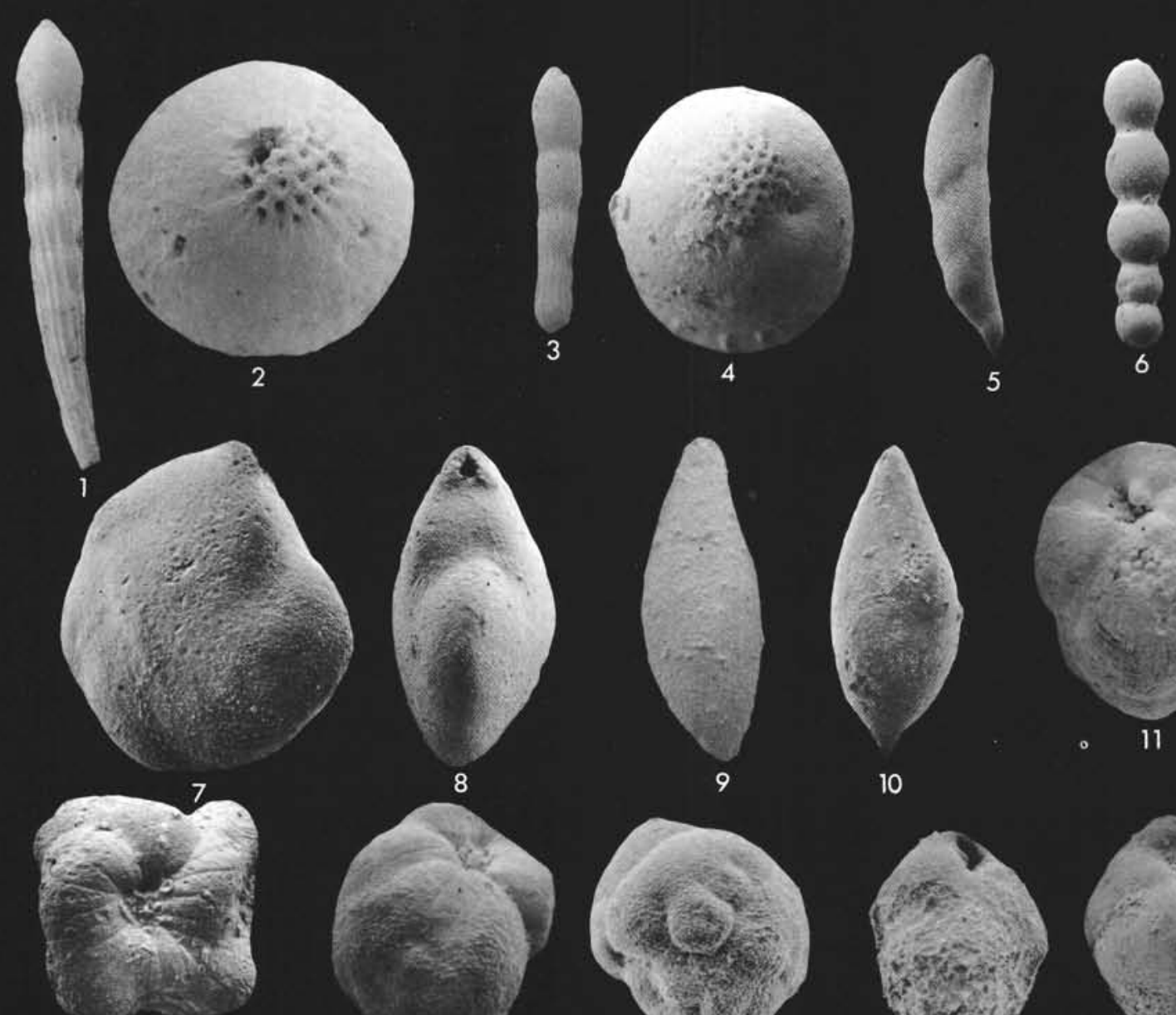

8
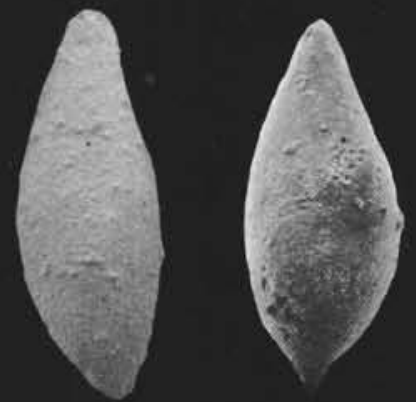

9


10

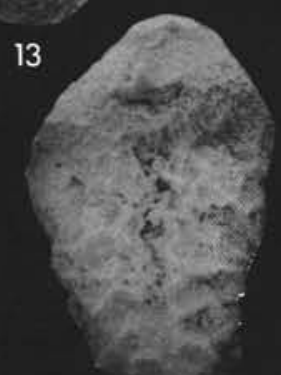

14

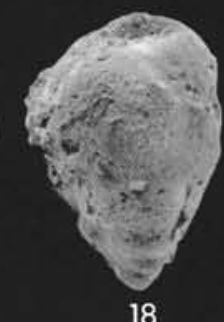

18
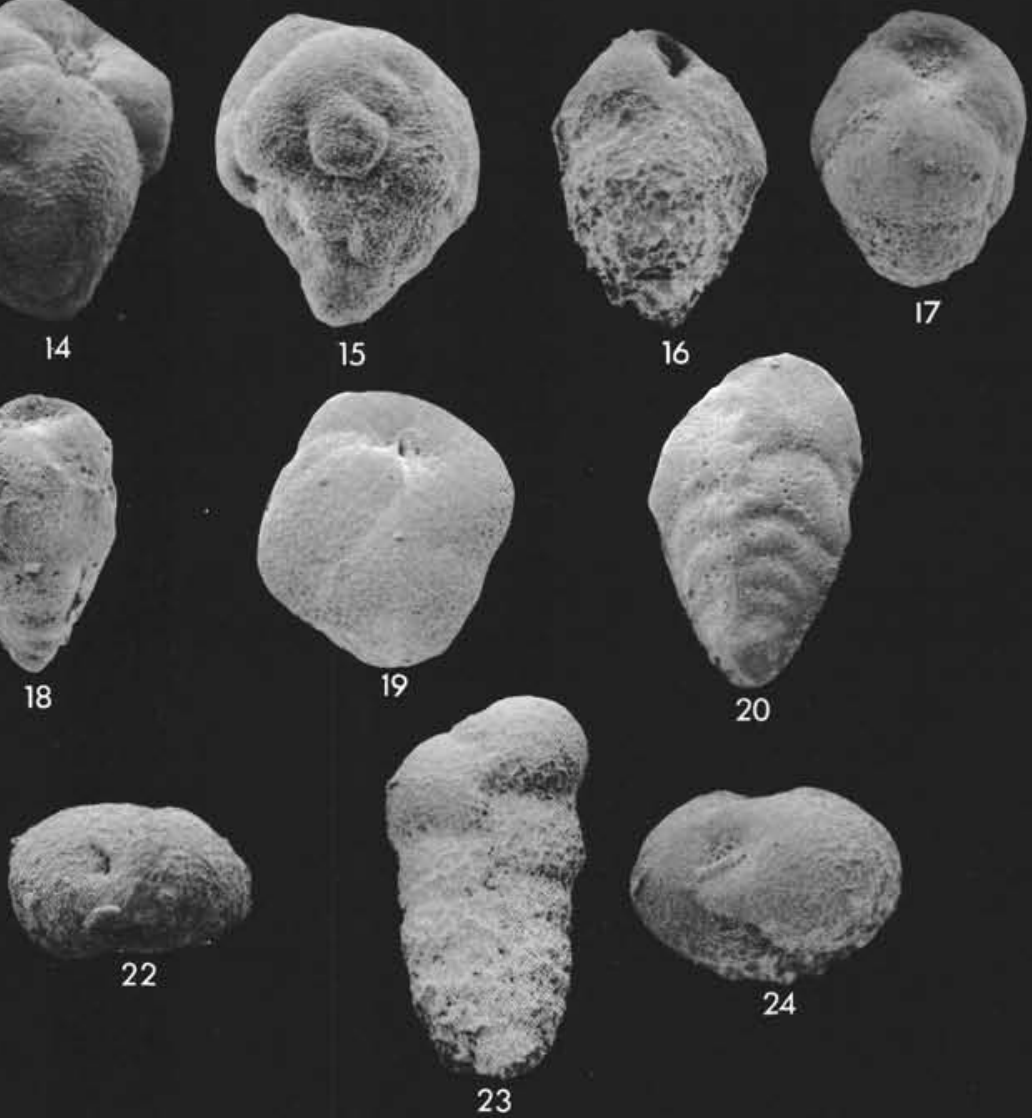
PLATE 2

Figures 1-3 Bolivinoides delicatulus Cushman, Bolivinoides decorata (Jones) var. delicatula Cushman, 1927, Cushman Lab. Foram. Res., Contrib., v. 2, p. 90, pl. 12, fig. 8. Sample 401-14, CC. Length of specimen $0.27 \mathrm{~mm}$. Figure $3, \times 400$.

Figures 4, 5 Tappanina selmensis (Cushman). Bolivinita selmensis Cushman, 1933, Cushman Lab. Foram. Res., Contrib., v. 9, p. 58, pl. 7. fig. 3, 4. Sample 400A-57-2, 4-7 $\mathrm{cm}$. Length of specimen $0.28 \mathrm{~mm}$.

Figure 6 Stilostomella gracillima (Cushman and Jarvis). Ellipsonodosaria nuttalli var. gracillima Cushman and Jarvis, 1934, Cushman Lab. Foram. Res., Contrib., v. 10, p. 72 , pl. 10 , fig. 7 . Sample $400-7-5,87-91 \mathrm{~cm}$. Length of specimen $0.74 \mathrm{~mm}$.

Figure 7 Stilostomella plummerae (Cushman). Ellipsonodosaria plummerae Cushman, 1940, Cushman Lab. Foram. Res., Contrib., v. 16, p. 69, pl. 12, fig. 4, 5. Sample 401-17, CC. Length of specimen $0.85 \mathrm{~mm}$.

Figure 8 Stilostomella subspinosa (Cushman). Ellipsonodosaria subnodosa Cushman, 1943, Cushman Lab. Foram. Res., Contrib., v. 19, p. 92, pl. 16, fig. 6, 7. Sample 401-2, CC. Length of specimen $0.63 \mathrm{~mm}$.

Figure 9 Stilostomella caribea (Palmer and Bermudez). Ellipsonodosaria caribea Palmer and Bermudez, 1936, Soc. Cubana Hist. Nat., Mem., v. 10, p. 297, pl. 18, fig. 10, 11. Sample 401-17, CC. Length of specimen $0.65 \mathrm{~mm}$.

Figure 10 Stilostomella decurta (Bermudez). Ellipsonodosaria decurta Bermudez, 1937, Soc. Cubana Hist. Nat., Mem., v. 11, p. 144, pl. 17, fig. 13, 14. Sample 400A-45, CC. Length of specimen $0.49 \mathrm{~mm}$.

Figures 11, 12 Bulimina consanguinea Parker and Bermudez, 1937, J. Paleontol., v. 11, p. 515, pl. 59, fig. 2. Sample $401-7-5,87-91 \mathrm{~cm}$. Length of specimen $0.39 \mathrm{~mm}$.

Figures 13, 14 Bulimina denticulata Cushman and Parker, 1936, Cushman Lab. Foram. Res., Contrib., v. 12, p. 42, pl. 2, fig. 7, 8. Sample 401-14, CC. Length of specimen $0.29 \mathrm{~mm}$.

Figures 15, 16 Bulimina jarvisi Cushman and Parker, 1936, Cushman Lab. Foram. Res., Contrib., v. 12 , p. 39 , pl. 7 , fig. 1. Sample $401-2$, CC. Length of specimen $0.71 \mathrm{~mm}$.

Figures 17, 18 Bulimina palmerae Parker and Bermudez, 1937, J. Paleontol., v. 11, p. 514, pl. 59, fig. 1. Sample 401-17, CC. Length of specimen $0.23 \mathrm{~mm}$.

Figures 19, 20 Bulimina pupoides Orbigny, 1846, Foram. Foss. Bass. Tert. Vienne, p. 185, pl. 11, fig. 11,12 . Sample $400 \mathrm{~A}-59-1,5-7 \mathrm{~cm}$. Length of specimen $0.29 \mathrm{~mm}$.

Figures 21, 22 Bulimina semicostata Nuttall, 1930, J. Paleont., v. 4, p. 286, pl. 23, fig. $15,16$. Sample 401-2, CC. Length of specimen $0.45 \mathrm{~mm}$.

Figure 23 Bulimina trinitatensis Cushman and Jarvis, 1928, Cushman Lab. Foram. Res., Contrib., v. 4, p. 102, pl. 14, fig. 12. Section 401-7-5, 87-91 cm. Length of specimen $0.56 \mathrm{~mm}$. 
PLATE 2
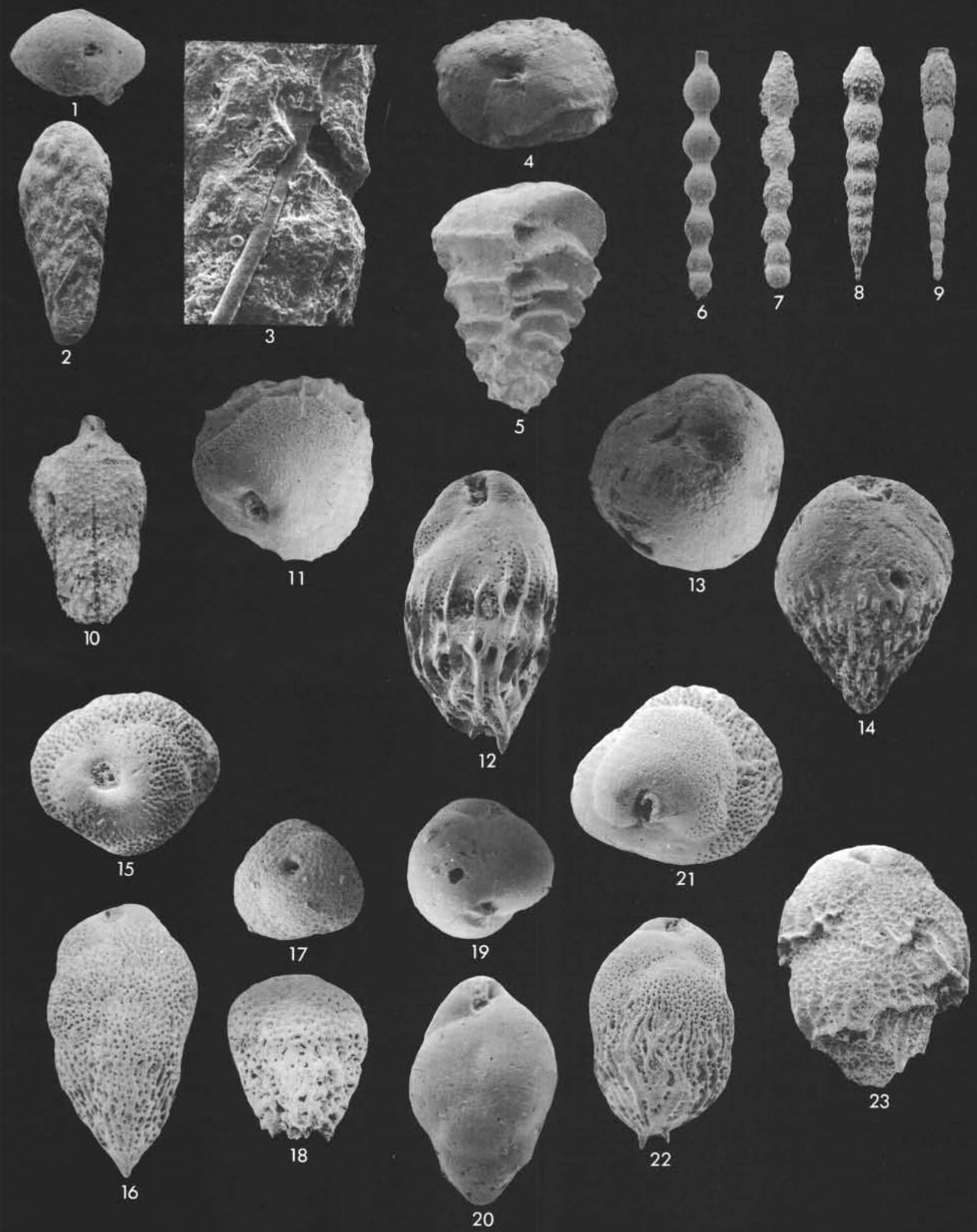


\section{PLATE 3}

Figures 1, 2 Bulimina tuxpamensis Cole, 1928, Am. Paleontol. Bull.,v. 14, p. 212, pl. 1, fig. 23. Sample 401-17, CC. Length of specimen $0.26 \mathrm{~mm}$.

Figure 3 Uvigerina spinicostata Cushman and Jarvis, 1929, Cushman Lab. Foram. Res., Contrib., v. 5, p. 12, pl. 3 , fig. 9, 10. Sample 401-7-5, 87-91 cm. Length of specimen $0.37 \mathrm{~mm}$.

Figure $4 \quad$ Rectuvigerina transversa (Cushman). Siphogenerina raphanus (Parker and Jones) var. transversus Cushman, 1918, U.S. Natl. Mus., Bull. 103, p. 64, pl. 22 , fig. 8. Sample 401-14, CC. Length of specimen $0.43 \mathrm{~mm}$.

Figure 5 Siphogenerina senni Cushman and Renz, 1941, Cushman Lab. Foram. Res., Contrib., v. 17, p. 22, pl. 3 , fig. 21,22 . Sample 400 A- 45 , CC. Length of specimen $0.52 \mathrm{~mm}$.

Figure 6 Trifarina sp. Sample 400A-51-6, 93-96 cm. Length of specimen $0.28 \mathrm{~mm}$.

Figures 7-9 Rosalina sp. Sample 402-5, CC. Length of specimen $0.27 \mathrm{~mm}$.

Figures 10-12 Stetsonia sp., cf. S. danvillensis (Howe and Wallace). Fide: Mallory, 1959, L. Tert. Biostrat. Cal. Coast. Ranges, p. 240, pl. 21, fig. 6. Sample 401-2, CC. Diameter of specimen $0.26 \mathrm{~mm}$.

Figures 13-15 Valvulineria sp. Sample 402-3, CC. Diameter of specimen $0.27 \mathrm{~mm}$.

Figures 16-18 Heronallenia sp. Sample 401-2, CC. Diameter of specimen $0.23 \mathrm{~mm}$.

Figures 19-21 Siphonina advena Cushman, 1922, U.S. Geol. Survey, Prof. Paper 129-E, p. 98, pl. 22, fig. 1, 2. Sample 402-5, CC. Diameter of specimen $0.26 \mathrm{~mm}$.

Figures 22-24 Nuttallides truempyi (Nuttall). Eponides truempyi Nuttall, 1930, J. Paleontol., v. 4, p. 271, pl. 24, fig. 9, 13, 14. Sample 401-13, CC. Diameter of specimen 0.45 $\mathrm{mm}$. 
PLATE 3
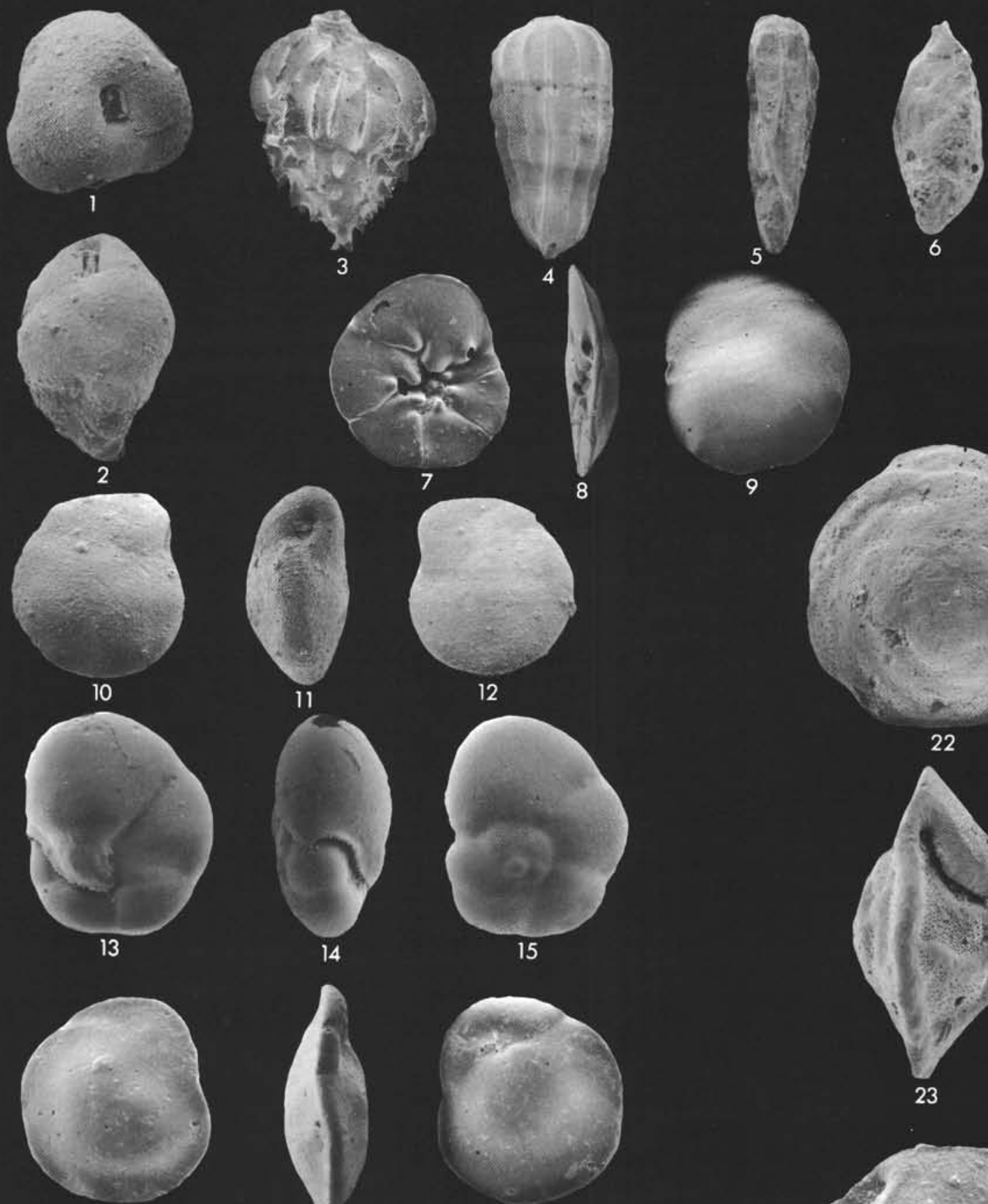

9
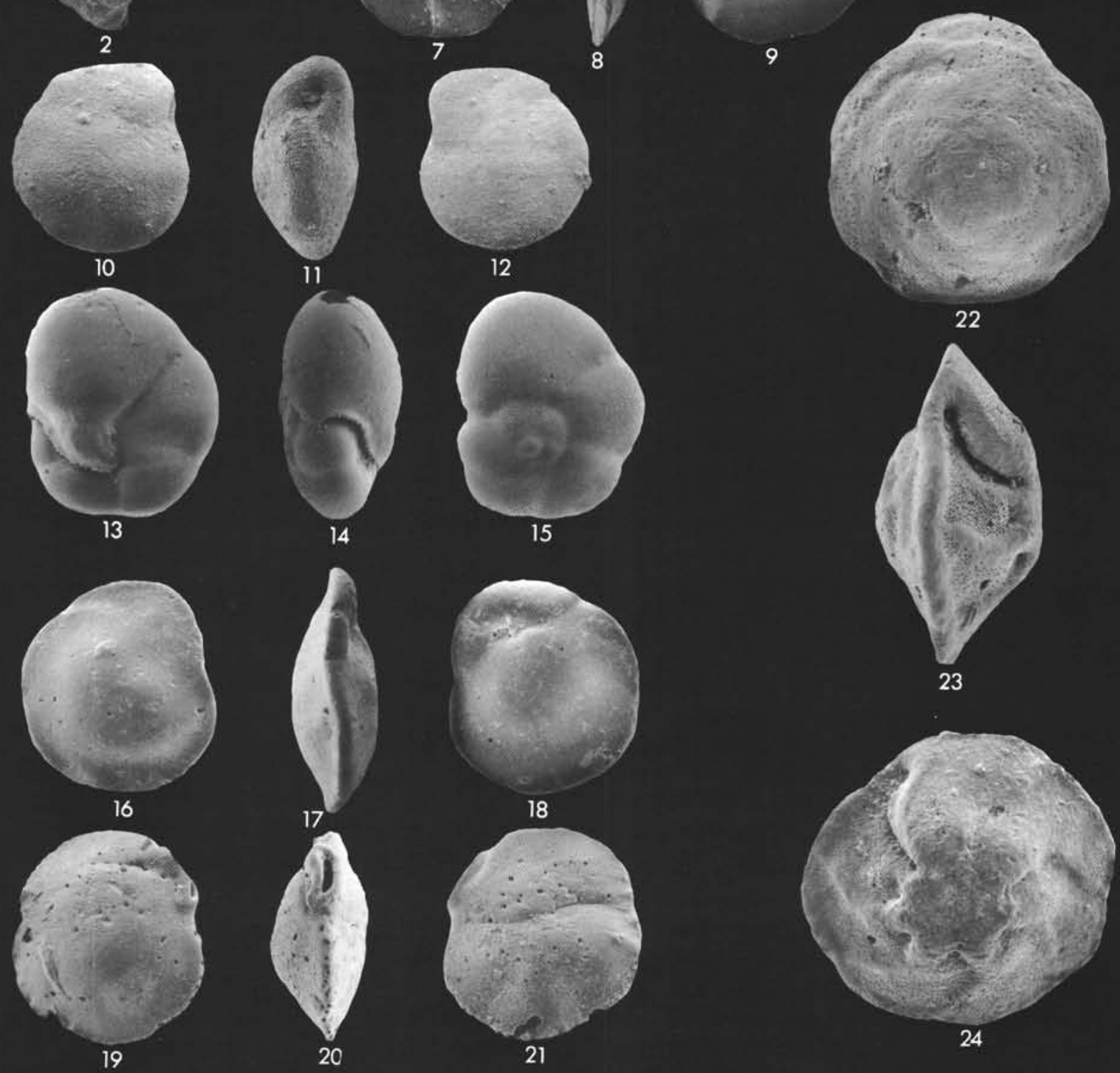


\section{PLATE 4}

Figures 1-3 Eponides bollii Cushman and Renz, 1946, Cushman Lab. Foram. Res., Spec. Publ., v. 18, p. 44, pl. 7, fig. 23. Sample 401-14, CC. Diameter of specimen 0.33 $\mathrm{mm}$.

Figures 4-6 Eponides bronnimanni Cushman and Renz, 1946, Cushman Lab. Foram. Res., Spec. Publ., v. 18, p. 45, pl. 7, fig. 24. Sample 401-14, CC. Diameter of specimen $0.23 \mathrm{~mm}$.

Figures 7-9 Eponides hillebrandti (Fisher). Neoeponides hillebrandti Fisher, 1969, Palaeontol., v. 12, p. 197. Sample 401-17, CC. Diameter of specimen $0.59 \mathrm{~mm}$.

Figures 10-12 Eponides lotus (Schwager). Pulvinulina lotus Schwager, 1883, Palaeontogr., v. 30, Abt. 1, p. 132, pl. 28, fig. 9. Sample 401-16, CC. Diameter of specimen $0.40 \mathrm{~mm}$.

Figures 13-15 Eponides sp., cf. E. subcandidulus (Grzybowsky). Fide: Hillebrandt, 1962, Bayer. Akad. Wiss., math.naturw. K1., Abh. N.F., pl. 7, fig. 12. Sample 40117 , CC. Diameter of specimen $0.50 \mathrm{~mm}$.

Figures 16-19 Planulina ammophila (Guembel). Rotalia ammophila Guembel, 1868, K. Bayer. Akad. Wiss., II Cl., Abh., v. 10 , p. 652 , pl. 2. Fig. 19: detail of test wall: calcite rhombs and coccoliths, $\times 1100$. Sample 400A-56-2, $60-63 \mathrm{~cm}$. Diameter of specimen $0.21 \mathrm{~mm}$. 
PLATE 4
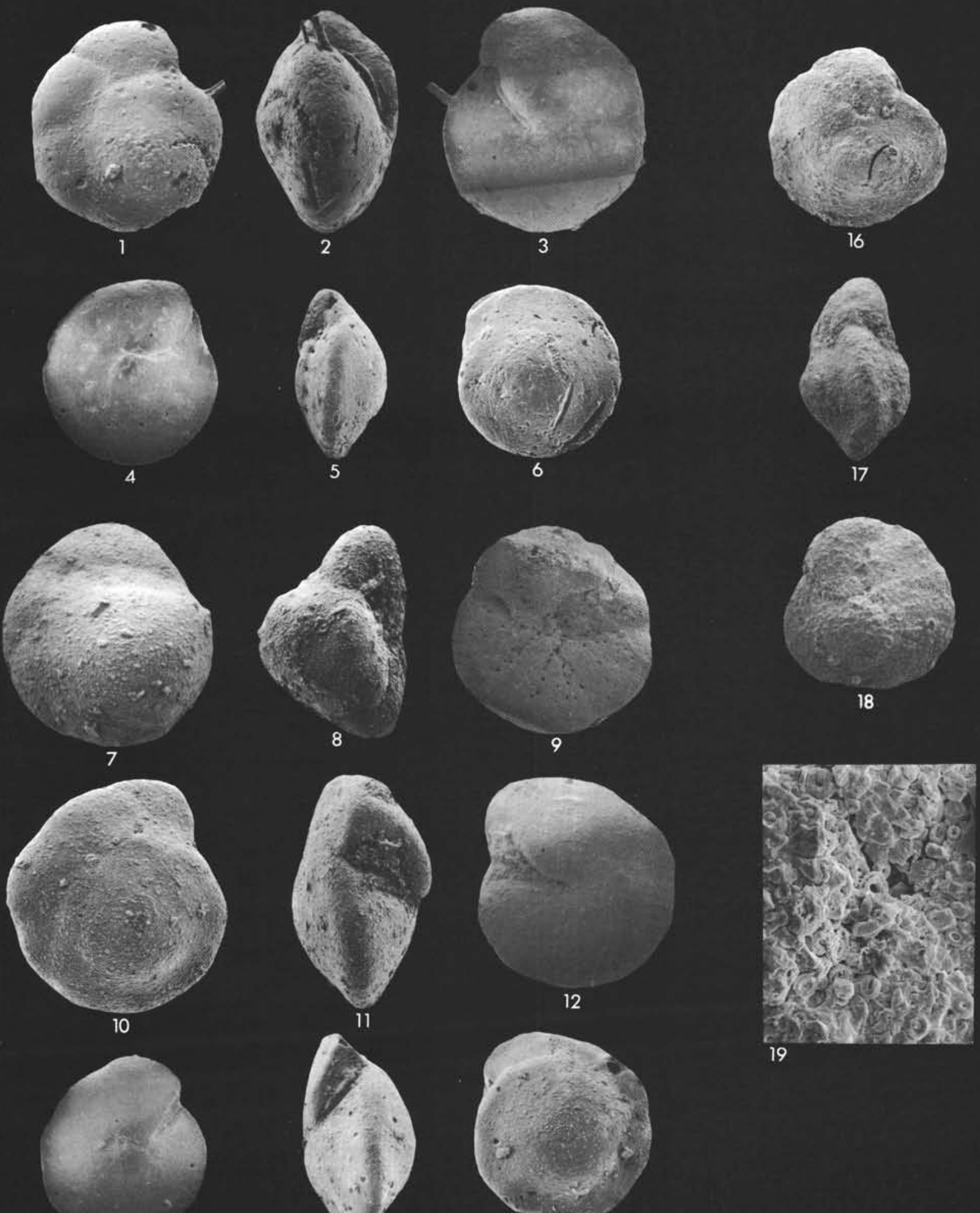

13


19 


\section{PLATE 5}

Figures 1-3 Planulina renzi Cushman and Stainforth, 1945, Cushman Lab. Foram. Res., Spec. Publ., v. 14, p. 72, pl. 15, fig. 1. Sample 400A-45, CC. Diameter of specimen 0.52 $\mathrm{mm}$.

Figure 4

Pleurostomella bierigi Palmer and Bermudez, 1936, Soc. Cubana Hist. Nat., Mem. 10 , p. 294 , pl. 17, fig. 7,8 . Sample $401-2$, CC. Length of specimen $0.35 \mathrm{~mm}$.

Figure 5 Pleurostomella subcylindrica (Cushman). Nodosarella subcyclindrica Cushman, 1943, Cushman Lab. Foram. Res., Contrib., v. 19, p. 91, pl. 16, fig. 4. Sample $400 \mathrm{~A}-51-6,93-96 \mathrm{~cm}$. Length of specimen $0.75 \mathrm{~mm}$.

Figure 6 Ellipsodimorphina subcompacta Liebus, 1922, Lotos, v. 70, p. 57, pl. 2, fig. 13. Sample 400A-55, CC. Length of specimen $1.25 \mathrm{~mm}$.

Figure 7 Ellipsoglandulina exponens (Brady). Ellipsoidina exponens Brady, 1892, Quart. J. Geol. Soc. London, v. 48, p. 198. Fide: Beckmann, 1953, Eclog. Geol. Helv., v. 46 , p. 378. Sample $400 \mathrm{~A}-45$, CC. Length of specimen $0.88 \mathrm{~mm}$.

Figure $8 \quad$ Ellipsoglundulina labiata (Schwager). Glandulina labiata Schwager, 1866, Nov.Exped., Geol. Teil, v. 2, p. 237, pl. 6, fig. 77. Sample 401-13, CC. Length of specimen $0.55 \mathrm{~mm}$.

Figure 9 Ellipsoglandulina principiens Cushman and Bermudez, 1937, Cushman Lab. Foram. Res., Contrib., v. 13, p. 18, pl. 2, fig. 1, 2, 3. Sample 400A-58, CC. Length of specimen $0.75 \mathrm{~mm}$.

Figure 10 Ellipsopolymorphina sp. Sample 400A-58, CC. Length of specimen $0.56 \mathrm{~mm}$.

Figure $11 \quad$ Nodosarella subnodosa (Guppy). Ellipsoidina subnodosa Guppy, 1894, Zool. Soc. London Proc., p. 650, pl. 61, fig. 12. Sample 400A-51-6, 93-96 cm. Length of specimen $0.96 \mathrm{~mm}$.

Figures 12, 13 Bandyella beckmanni Proto Decima and Bolli, in press, DSDP Init. Rept., v. 40, p. 000 , pl. 3, fig. 12. Sample 400A-58, CC. Length of specimen $0.36 \mathrm{~mm}$.

Figures 14, 15 Aragonia anauna Cita, 1960, Soc. Pal. Ital., Boll., v. 1, p. 78, fig. 1-4. Sample $401-13$, CC. Length of specimen $0.28 \mathrm{~mm}$.

Figures 16, 17 Aragonia byramensis (Cushman). Bolivina coelata var. byramensis Cushman, 1923, U.S. Geol. Survey Prof. Paper, p. 19, pl. 1, fig. 9. Sample 400A-45, CC. Length of specimen $0.35 \mathrm{~mm}$.

Figures 18-21 Aragonia capdevilensis (Cushman and Bermudez). Bolivina capdevilensis Cushman and Bermudez, 1937, Cushman Lab. Foram. Res., Contrib., v. 13, p. 14, pl. 1, fig. 49, 50.

18, 19. Sample 401-11-4, $94-97 \mathrm{~cm}$. Length of specimen $0.32 \mathrm{~mm}$.

20 , 21. Sample $401-11-4,94-97 \mathrm{~cm}$. Length of specimen $0.34 \mathrm{~mm}$.

Figures 22, 23 Aragonia ouezzanensis (Rey). Bolivinoides ouezzanensis Rey, 1955, Soc. Geol. France, Bull. Ser. 6, v. 4, fasc. 4-6, p. 210, pl. 12, fig. 2. Sample 401-17, CC. Length of specimen $0.31 \mathrm{~mm}$.

Figures 24, 25 Aragonia velascoensis (Nuttall). Textularia velascoensis Nuttall, 1930, J. Paleontol., v. 4, p. 280, pl. 23, fig. 6. Sample 401-17, CC. Length of specimen $0.75 \mathrm{~mm}$. 


\section{PLATE 5}

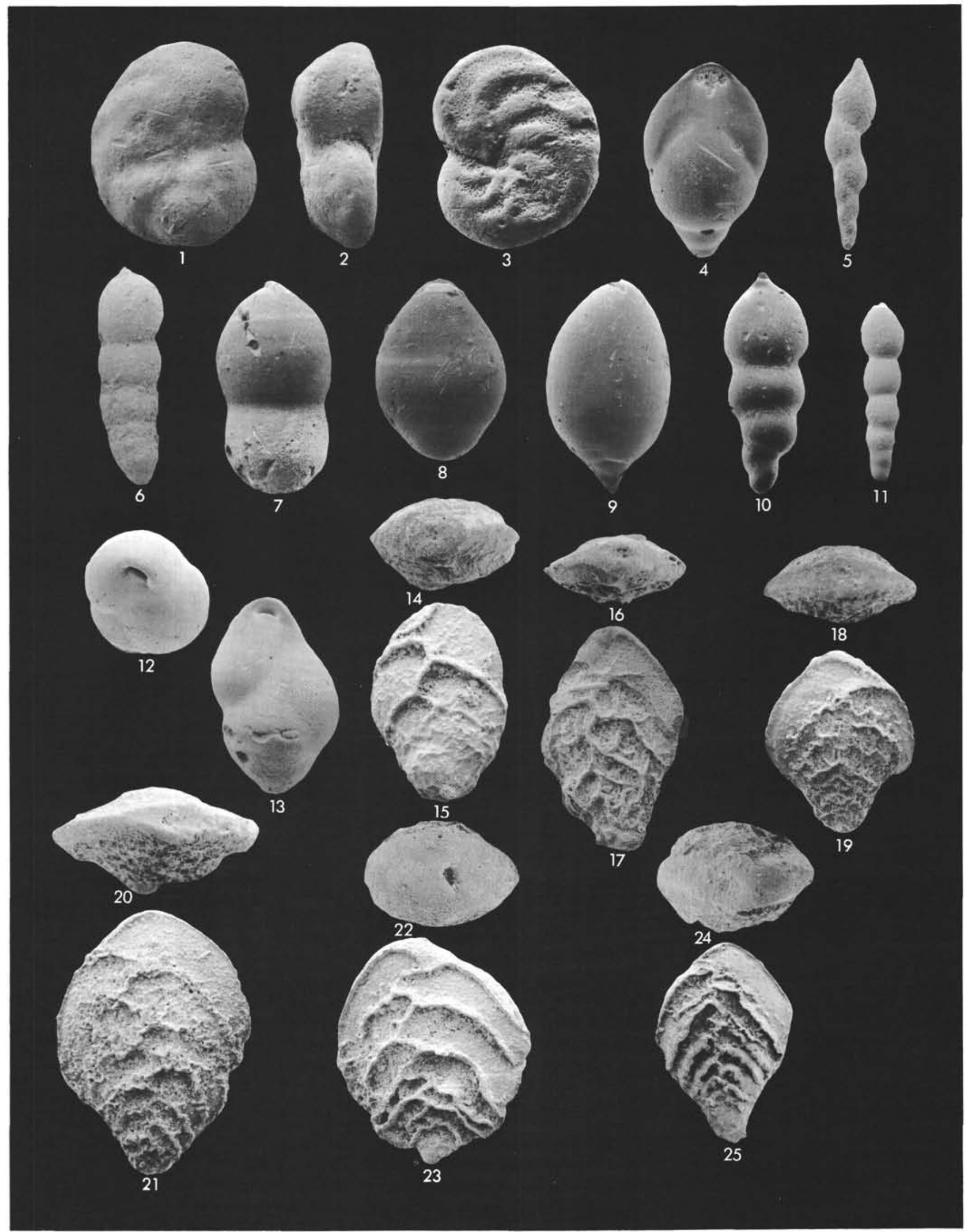




\section{PLATE 6}

The species assembled on this plate are common in many Paleocene and Eocene samples from Hole 400A and Site 401; they occur in South Atlantic material as well.

Their generic assignment here is only tentative, awaiting the results of a detailed morphologic-systematic study of this plexus.

Figures 1-7 ?Allomorphinella sp.

1-3. Sample 400-51-6A, 93-96 cm. Diameter of specimen $0.26 \mathrm{~mm}$.

4-6. Sample 400-51-6A, 93-96 cm. Diameter of specimen $0.25 \mathrm{~mm}$.

7. Detail of etched surface. $\times 900$.

Figures 8-14 ?Quadrimorphina sp. 1.

8-10. Sample 400A-51-6, 93-96 cm. Diameter of specimen $0.25 \mathrm{~mm}$.

11-13. Sample 400A-51-6, 93-96 cm. Diameter of specimen $0.26 \mathrm{~mm}$.

14. Detail of smooth surface. $\times 1800$.

Figures 15-17 ?Quadrimorphina sp. 2. Sample 400A-49-1, 75-78 $\mathrm{cm}$. Diameter of specimen $0.29 \mathrm{~mm}$.

Figures 18-23 ?Quadrimorphina sp. 3.

18-20. Sample 440A-59-1, 5-7 cm. Diameter of specimen $0.31 \mathrm{~mm}$.

21-23. Sample 400A-59-1, 5-7 cm. Diameter of specimen $0.34 \mathrm{~mm}$. 

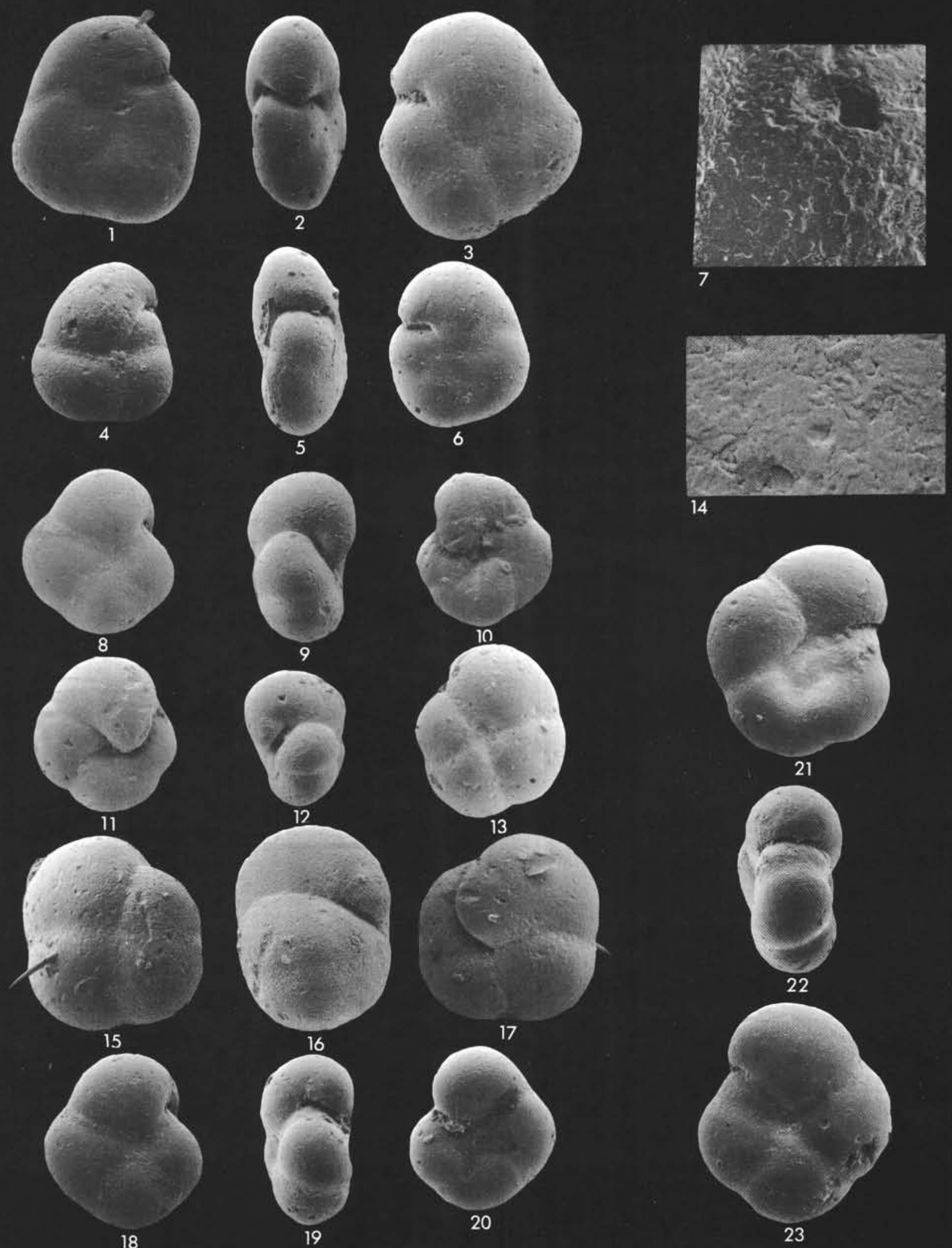

18 


\section{PLATE 7}

Figures 1, 2 Nonion havanaense Cushman and Bermudez, 1937, Cushman Lab. Foram. Res., Contrib. v. 13, p. 19, pl. 2 , fig. 13, 14. Sample 401-11-4, 95-97 cm. Diameter of specimen $0.35 \mathrm{~mm}$.

Figures 3-5 Astrononion australe Cushman and Edwards, 1937, Cushman Lab. Foram. Res., Contrib., v. 13, p. 33, pl. 3, fig. 13, 14. Sample 401-2, CC. Diameter of specimen $0.31 \mathrm{~mm}$.

Figures 6-8 Nonionella scaphum (Fichtel and Moll). Nautilus scapha Fichtel and Moll, 1798, Test. Micr., pl. 19, fig. d-f. Sample 402-5, CC. Diameter of specimen $0.33 \mathrm{~mm}$.

Figures 9, 10 Pullenia bulloides (Orbigny). Nonionina bulloides Orbigny, 1826, Ann. Sci. Nat., v. 7, p. 293. Sample 401-2, CC. Diameter of specimen $0.29 \mathrm{~mm}$.

Figures 11, 12 Pullenia coryelli White, 1929. J. Paleontol., v. 3, p. 56, pl. 5, fig. 22. Sample 401-14, CC. Diameter of specimen $0.29 \mathrm{~mm}$.

Figures 13, 14 Pullenia eocenica Cushman and Siegfus, 1939, Cushman Lab. Foram. Res., Contrib., v. 15, p. 31, pl. 7, fig. 1. Sample 401-13, CC. Diameter of specimen $0.38 \mathrm{~mm}$.

Figures 15, 16 Pullenia quinqueloba (Reuss). Nonionina quinqueloba Reuss, 1851, Z. Deutsch. Geol. Ges., v. 3, p. 71, pl. 5, fig. 31. Sample 401-13, CC. Diameter of specimen $0.39 \mathrm{~mm}$.

Figures 17, 18 Pullenia riveroi Bermudez, 1939, Soc. Cubana Hist. Nat., Mem., v. 13, p. 11, pl. 2, fig. 1-6. Sample 401-13, CC. Diameter of specimen $0.31 \mathrm{~mm}$.

Figures 19-21 Alabamina dissonata (Cushman and Renz). Pulvinulinella atlantisae Cushman, var. dissonata Cushman and Renz, 1948, Cushman Lab. Foram. Res., Spec. Publ., no. 24, p. 35, pl. 7, fig. 11, 12. Sample 400A-51-6, 93-96 cm. Diameter of specimen $0.48 \mathrm{~mm}$.

Figures 22-24 ?Alabamina sp. Sample 402-5, CC. Diameter of specimen $0.23 \mathrm{~mm}$. 


\section{PLATE 7}
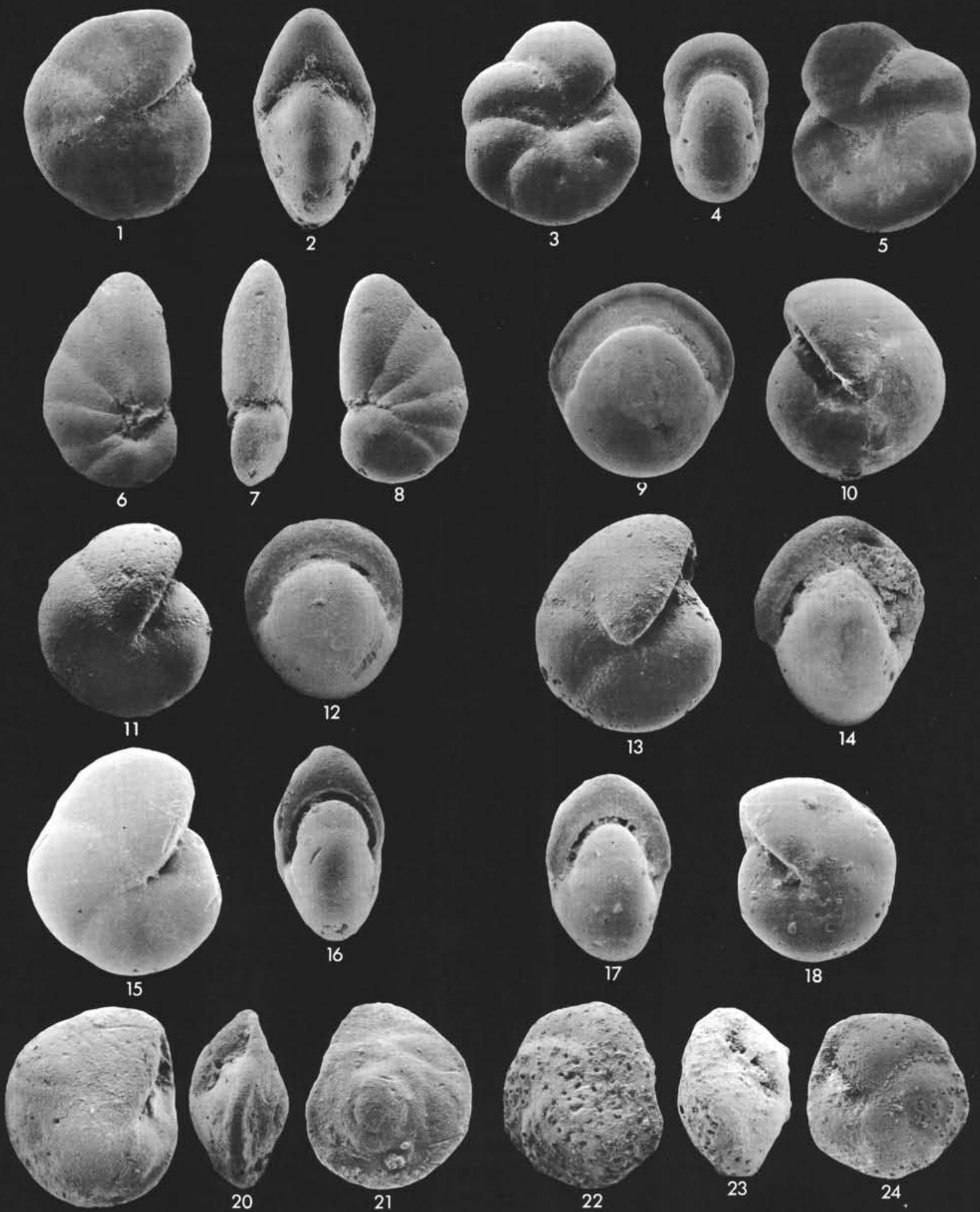

19

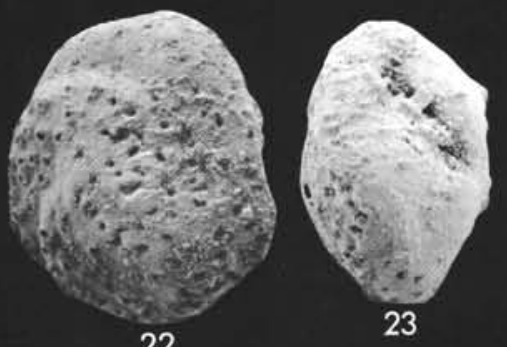

22

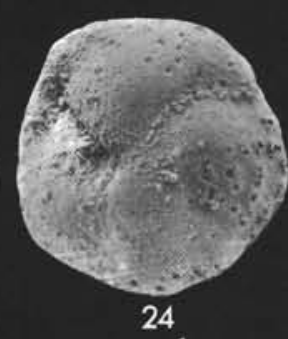




\section{PLATE 8}

Figures 1-3 Gyroidina girardana (Reuss). Rotalina girardana Reuss, 1851, Z. Deutsch. Geol. Ges., v. 3, p. 73, pl. 5, fig. 34. Sample 401-11-4, 95-97 cm. Diameter of specimen $0.34 \mathrm{~mm}$.

Figures 4-6 Oridorsalis umbonatus (Reuss). Rotalina umbonata Reuss, 1851, Z. Deutsch. Geol. Ges., v. 3, p. 75, pl. 5, fig. 35. Sample 401-9-6, 72-74 cm. Diameter of specimen $0.46 \mathrm{~mm}$.

Figures 7-9 Osangularia dominicana (Bermudez). Parella dominicana Bermudez, 1949, Cushman Lab. Foram. Res., Spec. Publ., v. 25, p. 272, pl. 21, fig. 4, 5, 6. Sample 401-2, CC. Diameter of specimen $0.27 \mathrm{~mm}$.

Figures 10-12 Osangularia mexicana (Cole). Pulvinulinella culter (Parker and Jones) var. mexicana Cole, 1927, Am. Paleontol., Bull, v. 14, p. 31, pl. 1, fig. 15, 16. Sample 401-7-5, 87-91 cm. Diameter of specimen $0.44 \mathrm{~mm}$.

Figures 13-15 Osangularia plummerae Brotzen, 1940, Sver. Geol. Unders., Avh. Ser. C, p. 30. Sample 401-17, CC. Diameter of specimen $0.38 \mathrm{~mm}$.

Figures 16-18 Charltonina sp. Sample 401-17, CC. Diameter of specimen $0.23 \mathrm{~mm}$.

Figures 19-21 Gyroidinoides beisseli (White). Gyroidina beisseli White, 1928, J. Paleontol., v. 2, p. 291, pl. 39, fig. 7. Sample 400A-56-2, 60-63 cm. Diameter of specimen $0.38 \mathrm{~mm}$. 


\section{PLATE 8}
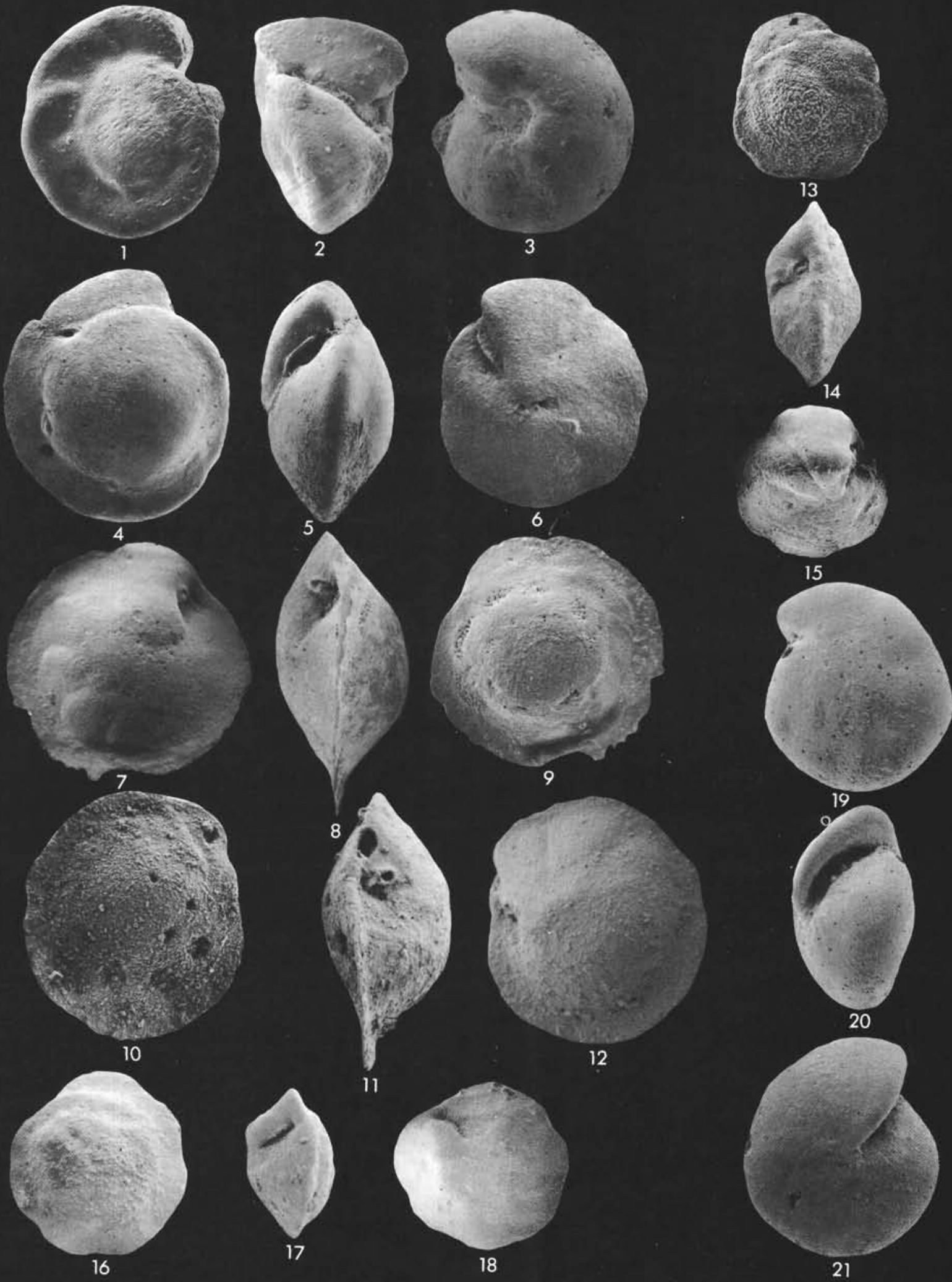


\section{PLATE 9}

Figures 1-3 Gyroidinoides complanata (Cushman and Stainforth). Gyroidina complanata Cushman and Stainforth, 1945, Cushman Lab. Foram. Res., Spec. Publ., v. 14, p. 61, pl, 11, fig. 2. Sample 401-7-5, 87-91 cm. Diameter of specimen $0.30 \mathrm{~mm}$.

Figures 4-6 Gyroidinoides globosa (Hagenow). Nonionina globosa Hagenow, 1842, N. Jb. Min., p. 574. Sample 401-17, CC. Diameter of specimen $0.46 \mathrm{~mm}$.

Figures 7-9 Gyroidinoides naranjoensis (White). Gyroidina naranjoensis White, 1928, J. Paleontol., v. 2, p. 296, pl. 40 , fig. 5. Sample 401-17, CC. Diameter of specimen $0.31 \mathrm{~mm}$.

Figures 10-12 Gyroidinoides planulata (Cushman and Renz). Gyroidina planulata Cushman and Renz, 1941, Cushman Lab. Foram. Res., Contrib., v. 17, p. 23, pl. 4, fig. 1. Sample 400A-56-2. Diameter of specimen $0.31 \mathrm{~mm}$.

Figures 13-15 Gyroidinoides subangulata (Plummer). Rotalia soldanii (Orbigny) var. subangulata Plummer, 1926, Univ. Texas Bull., p. 154, pl. 12, fig. 1. Sample 401-17, CC. Diameter of specimen $0.39 \mathrm{~mm}$.

Figures 16-18 Gyroidinoides sp. Sample 401-7-5, 60-63 cm. Diameter of specimen $0.22 \mathrm{~mm}$.

Figures 19-21 Anomalinoides alazanensis (Nuttall). Anomalina alazanensis Nuttall, 1932, J. Paleontol., v. 6, p. 32, pl. 8, fig. 5-7. Sample 400A-59-1, 5-7 cm. Diameter of specimen $0.35 \mathrm{~mm}$. 


\section{PLATE 9}

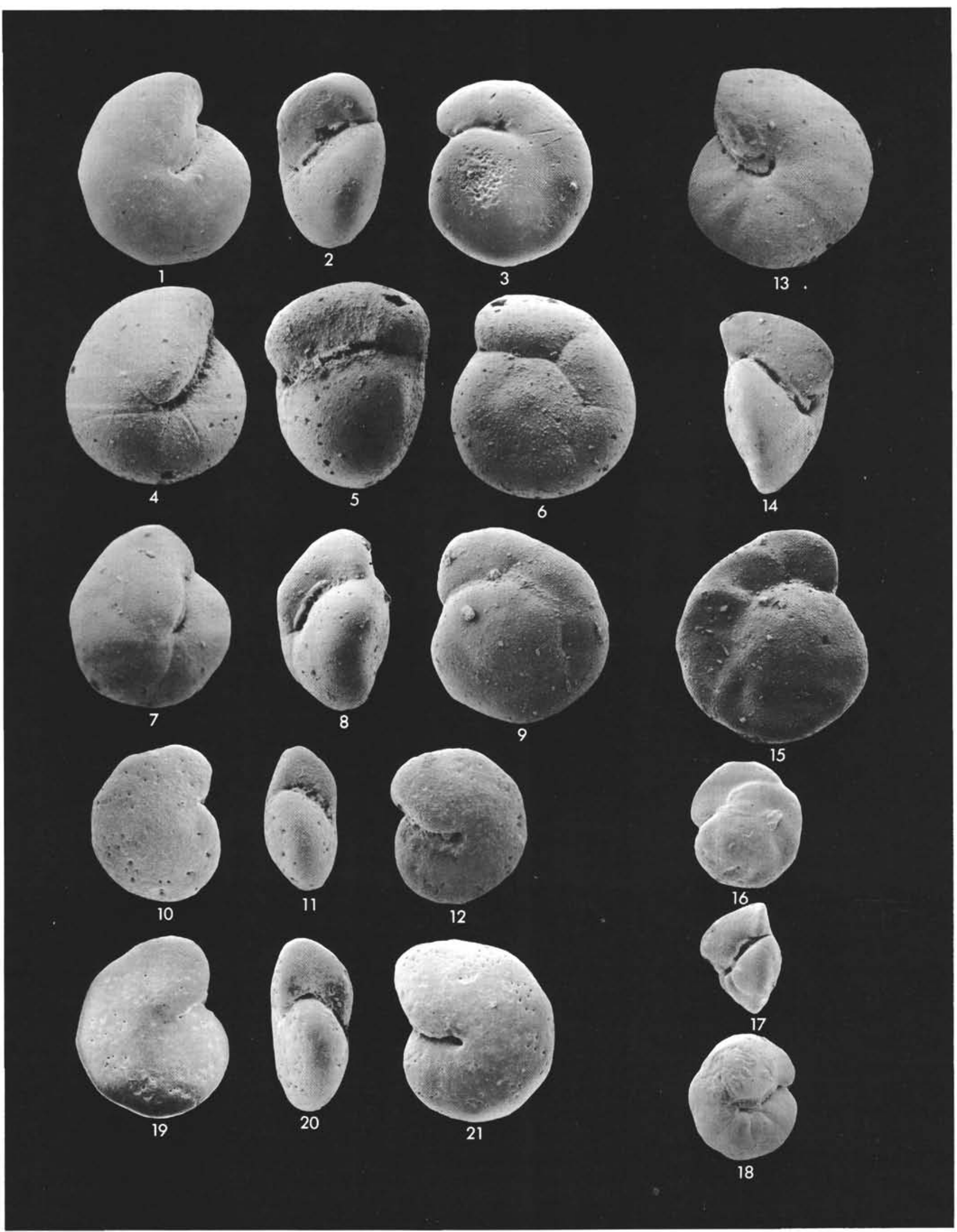




\section{PLATE 10}

Figures 1-3 Anomalinoides praespissiformis (Cushman and Bermudez). Anomalina praespissiformis Cushman and Bermudez, 1948, Cushman Lab. Foram. Res., Contrib., v. 24, p. 86, pl. 15, fig. 1, 2, 3. Sample 401-16, CC. Diameter of specimen $0.39 \mathrm{~mm}$.

Figures 4-6 Anomalinoides spissiformis (Cushman and Stainforth). Anomalina alazanensis Nuttall var. spissiformis Cushman and Stainforth, 1945, Cushman Lab. Foram. Res., Spec. Publ., v. 14, p. 71, pl. 14, fig. 5. Sample 400A-59-1, 5-7 cm. Diameter of specimen $0.33 \mathrm{~mm}$.

Figures 7-9 Anomalinoides sp. Sample 401-14, CC. Diameter of specimen $0.25 \mathrm{~mm}$.

Figures 10-12 Cibicidoides alazanensis (Nuttall). Planulina alazanensis Nuttall, 1932, J. Paleontol., v. 6, p. 31, pl. 7, fig. 4, 8, 9. Sample 401-11-4, 95-97 cm. Diameter of specimen $0.54 \mathrm{~mm}$.

Figures 13-15 Cibicidoides beckmanni, new name. Sample 401-9-6, $72-74 \mathrm{~cm}$. Diameter of specimen $0.85 \mathrm{~mm}$. The species described by Beckmann (1953, p. 404, pl. 28, fig. 9, 10) as Cibicides cf. trinitatensis (Nuttall) is not identical with Nuttall's species (Truncatulina trinitatensis Nuttall, 1928, Geol. Soc. London, Quart. J., v. 84 , p. 97 , pl. 7 , fig. 3, 5, 6). Because both species belong in the genus Cibicidoides, Nuttall's designation has priority over the combination Cibicidoides trinitatensis Beckmann (non Nuttall), formed by Berggren in 1972 (see also Douglas, 1973, p. 656). Beckman's specimen of pl. 28 , fig. 10 is here designated holotype for the species.

Figures 16-18 Cibicidoides cookei (Cushman and Garrett). Cibicides cookei Cushman and Garrett, 1938, Cushman Lab. Foram. Res., Contrib., v. 14, p. 65, pl. 11, fig. 3. Sample 400A-45, CC. Diameter of specimen 0.28 $\mathrm{mm}$.

Figures 19-21 Cibicidoides eocaena (Guembel). Rotalia eocaena Guembel, 1868, K. Bayer. Akad. Wiss., Abh, II Cl., v. 10 , p. 650 , pl. 2 , fig. 87 . Sample 400 A- $49-1,75-78$ $\mathrm{cm}$. Diameter of specimen $0.28 \mathrm{~mm}$. 


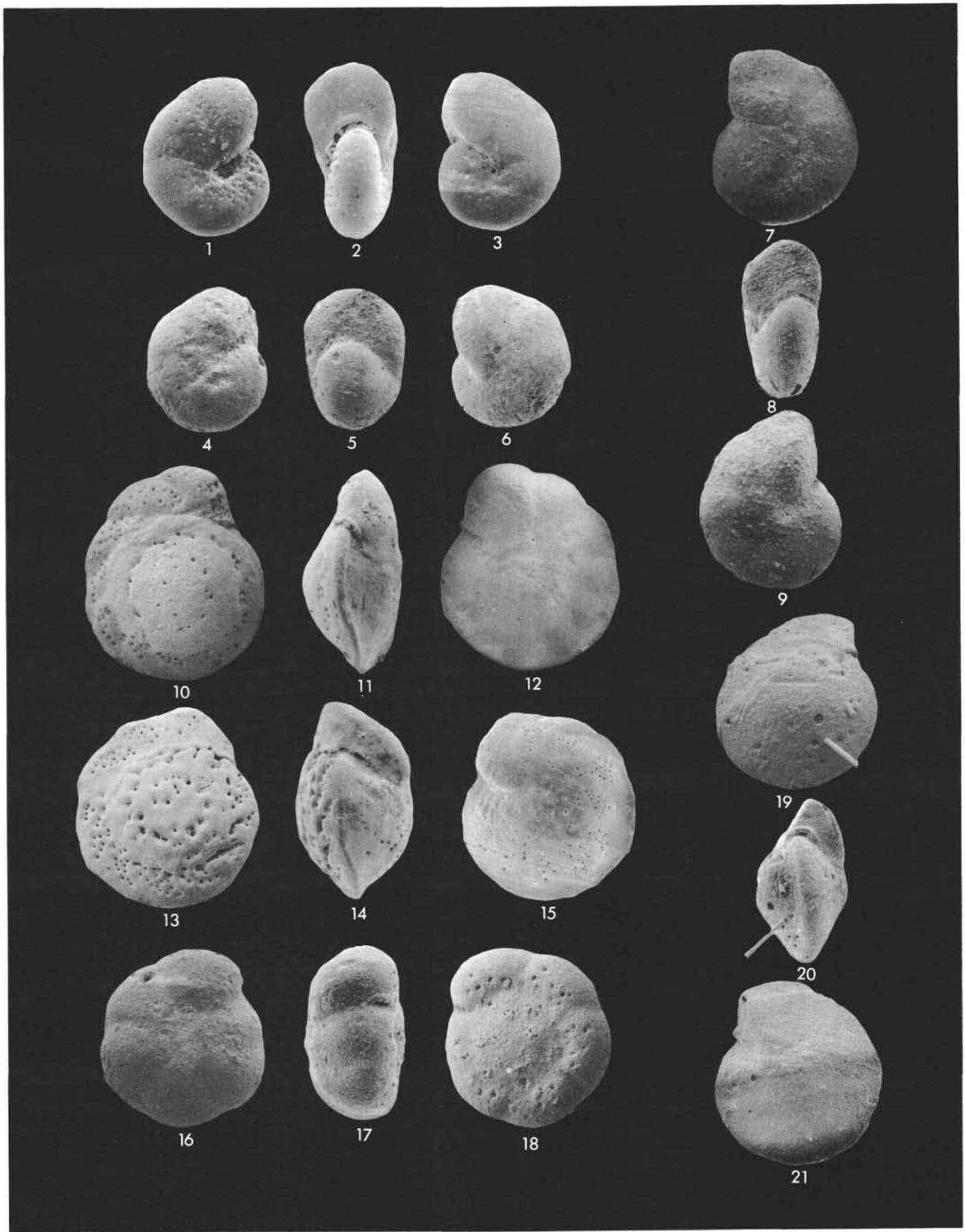




\section{PLATE 11}

Figures 1-3 Cibicidoides grimsdalei (Nuttall). Cibicides grimsdalei Nuttall, 1930, J. Paleontol., v. 4, p. 291, pl. 25, figs. 7, 8, 11. Sample 401-2, CC. Diameter of specimen $0.41 \mathrm{~mm}$.

Figures 4-6 Cibicidoides haitensis (Coryell and Rivero). Cibicides robertsonianus (Brady) var. haitensis Coryell and Rivero, 1940, J. Paleontol., v. 14, p. 335, pl. 44, fig. 4-6. Sample 401-7-5, 87-91 cm. Diameter of specimen $0.38 \mathrm{~mm}$.

Figures 7-9 Cibicidoides havanaensis (Cushman and Bermudez). Cibicides havanaensis Cushman and Bermudez, 1937, Cushman Lab. Foram. Res., Contrib., v. 13, p. 28, pl. 3 , figs. 1, 2, 3. Sample 400A-49-1, 75-78 cm. Diameter of specimen $0.55 \mathrm{~mm}$.

Figures 10-12 Cibicidoides perlucidus (Nuttall). Cibicides perlucidus Nuttall, 1932, J. Paleontol., v. 6, p. 33, pl. 8, figs. $10,11,12$. Sample 401-13, CC. Diameter of specimen $0.40 \mathrm{~mm}$.

Figures 13-15 Cibicidoides pseudoungerianus (Cushman). Truncatulina pseudoungeriana Cushman, 1922, U.S. Geol. Survey, Prof. Paper 129, p. 97, 131, pl. 20, fig. 9. Sample 401-13, CC. Diameter of specimen 0.53 $\mathrm{mm}$. 
PLATE 11
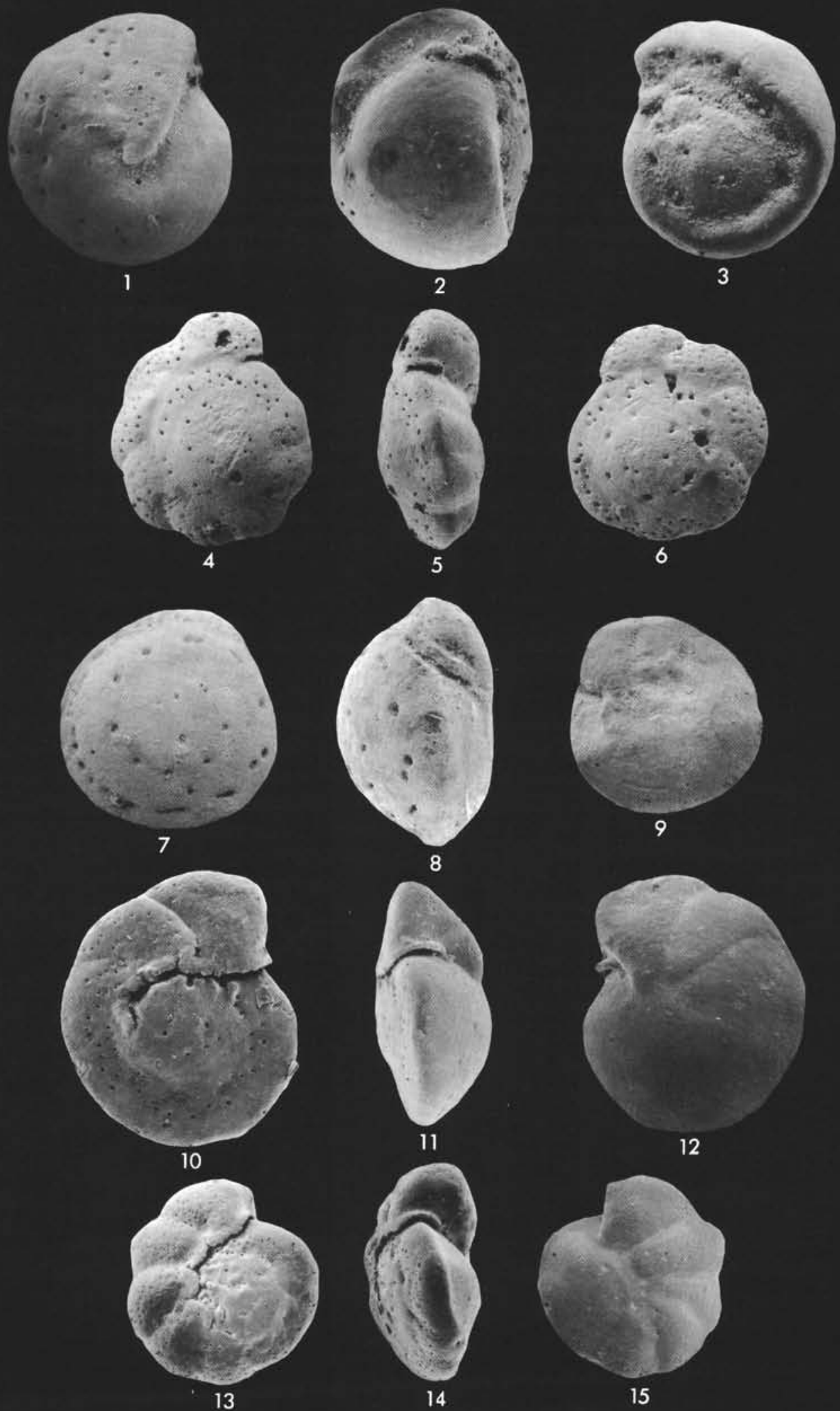


\section{PLATE 12}

Figures 1-3 Cibicidoides pseudowuellerstorfi (Cole). Cibicides pseudowuellerstorfi Cole, 1927, Am. Paleontol., Bull. v. 14, p. 36, pl. 1, fig. 13, 14. Sample 401-7-5, $87-91 \mathrm{~cm}$. Diameter of specimen $0.25 \mathrm{~mm}$.

Figures 4-6 Cibicidoides sinistralis (Coryell and Rivero). Cibicides sinistralis Coryell and Rivero, 1940, J. Paleontol., v. 14 , p. 335 , pl. 44 , fig. 12. Sample 401-7-5, 87-91 cm. Diameter of specimen $0.42 \mathrm{~mm}$.

Figures 7-9 Cibicidoides sp. Sample 401-9-6, 72-74 cm. Diameter of specimen $0.30 \mathrm{~mm}$.

Figures 10, 11 Gavelinella beccariiformis (White). Rotalia beccariiformis White, 1928, J. Paleontol., v. 2, p. 287, pl. 39, fig. 2-4. Sample 401-17, CC. Diameter of specimen $0.44 \mathrm{~mm}$.

Figures 12-14 Gavelinella micra (Bermudez). Cibicides micra Bermudez, 1949, Cushman Lab. Foram. Res., Spec. Publ., v. 25, p. 302, pl. 24, fig. 34-36. Sample 401-2, CC. Diameter of specimen $0.33 \mathrm{~mm}$. 


\section{PLATE 12}
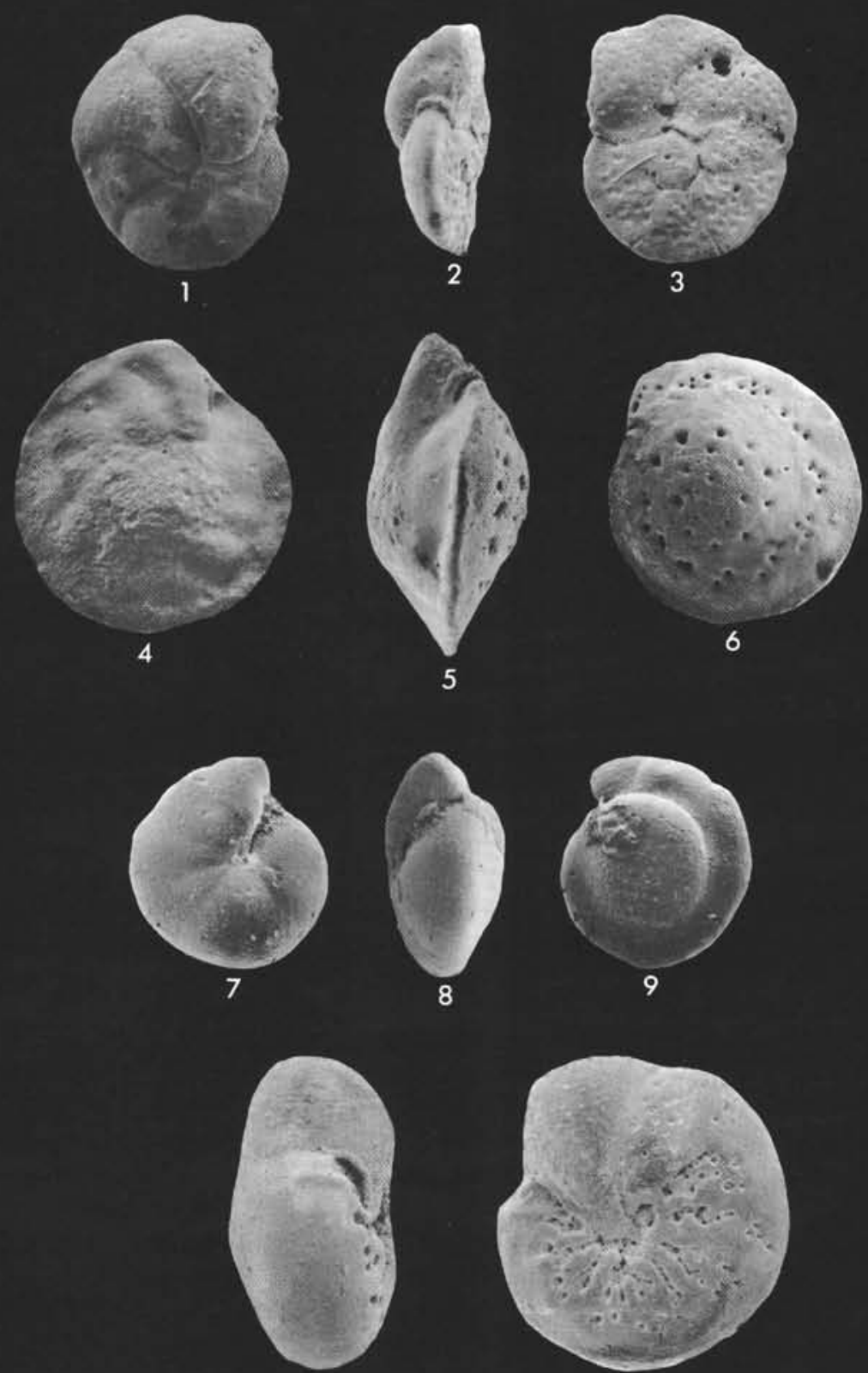

10
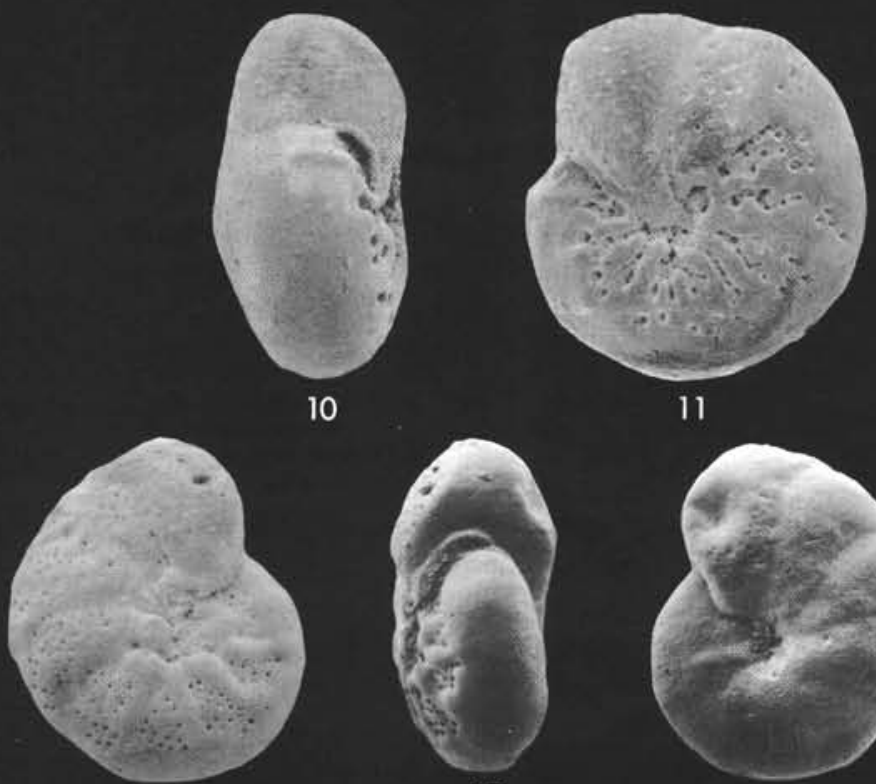

12

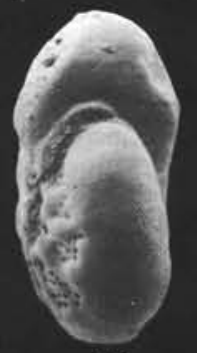

13

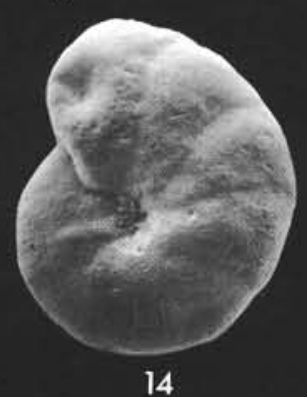

